\title{
Lactic Acid Bacteria as Antibacterial Agents to Extend the Shelf Life of Fresh and Minimally Processed Fruits and Vegetables: Quality and Safety Aspects
}

\author{
Sofia Agriopoulou ${ }^{1}$, Eygenia Stamatelopoulou ${ }^{1}$, Monika Sachadyn-Król ${ }^{2}$ (I) and \\ Theodoros Varzakas ${ }^{1, *}$ \\ 1 Department of Food Science and Technology, University of the Peloponnese, Antikalamos, \\ 24100 Kalamata, Greece; sagriopoulou@gmail.com (S.A.); estamatel@gmail.com (E.S.) \\ 2 Department of Chemistry, Faculty of Food Sciences and Biotechnology, University of Life Sciences in Lublin, \\ 20950 Lublin, Poland; monika.sachadyn-krol@up.lublin.pl \\ * Correspondence: theovarzakas@yahoo.gr; Tel.: +30-27210-45279
}

Received: 3 June 2020; Accepted: 22 June 2020; Published: 24 June 2020

check for updates

\begin{abstract}
Eating fresh fruits and vegetables is, undoubtedly, a healthy habit that should be adopted by everyone (particularly due to the nutrients and functional properties of fruits and vegetables). However, at the same time, due to their production in the external environment, there is an increased risk of their being infected with various pathogenic microorganisms, some of which cause serious foodborne illnesses. In order to preserve and distribute safe, raw, and minimally processed fruits and vegetables, many strategies have been proposed, including bioprotection. The use of lactic acid bacteria in raw and minimally processed fruits and vegetables helps to better maintain their quality by extending their shelf life, causing a significant reduction and inhibition of the action of important foodborne pathogens. The antibacterial effect of lactic acid bacteria is attributed to its ability to produce antimicrobial compounds, including bacteriocins, with strong competitive action against many microorganisms. The use of bacteriocins, both separately and in combination with edible coatings, is considered a very promising approach for microbiological quality, and safety for postharvest storage of raw and minimally processed fruits and vegetables. Therefore, the purpose of the review is to discuss the biopreservation of fresh fruits and vegetables through the use of lactic acid bacteria as a green and safe technique.
\end{abstract}

Keywords: lactic acid bacteria; biopreservation; edible coatings and films; fresh-cut fruits and vegetables; shelf life extension; food quality; microbiological quality; postharvest; storage; bacteriocins

\section{Introduction}

A healthy diet includes eating fruits and vegetables; their consumption is recommended by several government agencies because of their nutritional and medicinal properties [1] and low energy content [2]. Heart disease, colon cancer, obesity, and diabetes are some of the diseases that can be reduced with a high intake of fruits and vegetables [3]. Their consumption has increased in recent years, making them essential on a daily basis due to their abundance of nutrients [4]. In particular, in the last decade, the increased demand for fresh fruits and vegetables (whole and cut) in many industrialized nations has been covered partly from the production of minimally processed fruits and vegetables, as they are healthy and convenient foods. Traditional methods tend to be replaced by minimal processing methods, by providing fruits and vegetables that retain their quality for more than the usual time [5,6]. Two groups of molecules in the chemical composition of fruits and vegetables exist: nutritive molecules and non-nutritive phytochemicals [7]. Among nutritive molecules, 
vitamins, minerals, fibers, and micro and macronutrients are the most important, while phenolic compounds, flavonoids, and bioactive peptides belong to non-nutritive phytochemicals and have beneficial properties for human health [7]. The beneficial effect of all these molecules is proved in their action as receptors against free radicals [8]. According to the recent edition of Dietary Guidelines for Americans, published in 2016, from the U.S. Department of Health and Human Services (HHS) and U.S. Department of Agriculture (USDA), fruits and vegetables, should hold half the daily energy intake [9]. Moreover, vegetables with different colors (red, green, orange) from all categories, and whole fruits, are key recommendations in a healthy eating pattern. According to the International Fresh-Cut Produce Association (IFPA), fresh-cut produce is defined as "any fruit or vegetable or combination thereof that has been physically altered from its original form, but remains in a fresh state" [10]. Fresh-cut fruits and vegetables can be washed, trimmed, peeled, and chopped, creating 100\% easy-to-use products that are still fresh, maintaining all of the characteristics during packaging (without further processing) and under refrigeration [11]. 'Ready-to-eat', 'fresh-cut', 'easy- to-use', or 'pre-cut produce' are some others designations used for minimally processed fruits and vegetables [12].

Fresh-cut fruits and vegetables are extremely perishable products that have a very short shelf life and physiological deterioration; biochemical changes and microbial degradation can occur during their marketing. All of these changes can cause significant degradation in quality of characteristics, such as color, aroma, and taste, and lead to the growth of undesired and harmful pathogens, limiting shelf life [5]. In addition, even minimal processing of fresh fruits and vegetables, such as cutting and peeling, leads to the leakage of cellular content around the injuring points, increasing the risk of a microbial infection, as these points are full of minerals, sugars, vitamins, and other nutrients [13,14]. Moreover, upcoming rapid tissue aging can significantly reduce the life of fresh-cut fruits and vegetables [15]. Browning, softening, and off-flavor development are some of the signs that may appear in fresh fresh-cut fruits and vegetables [16]. Mechanical wounding of fresh fresh-cut fruits and vegetables also increases the rate of respiration, which is directly connected with short postharvest life [17]. These products are ready for consumption without any further possible microbiological treatment, so quality and safety issues are very urgent for consumer health [6]. Damage to the outer surface of cut fruits and vegetables favors the survival and proliferation of foodborne pathogens, especially at temperatures above $4{ }^{\circ} \mathrm{C}$. Lower temperatures can ensure a reduction in dynamic multiplication, but do not completely stop the survival of some microorganisms [18]. Microbial growth, in the case of fresh-cut fruits and vegetables, is significantly favored by the high water content of a large number of chopped tissues, as well as by the low or neutral $\mathrm{pH}$ that has the most vegetables and fruits, respectively [19].

In order to prolong storage life of fresh and minimally processed fruits and vegetables, many physical, chemical, and biological means and treatments have been proposed. Disinfection and washing are the main procedures used to reduce the population of pathogenic microorganisms (including their effect on the safety and quality of fresh and minimally processed fruits and vegetables). Among them, chlorine is a predominant treatment, which is added to water used to wash fresh-cut fruits and vegetables, although it has limited antimicrobial efficacy as it can only achieve 1-2 logarithmic reductions in pathogenic microorganisms [20]. The use of chlorine as a sanitizing agent poses serious risks to human health due to production of carcinogenic halogenated compounds [15]. European countries, such as Germany, Switzerland, the Netherlands, Denmark, and Belgium have taken into account all of the health issues that have arisen, and have banned the use of chlorine in disinfection of fresh and minimally processed fruits and vegetables. Another widely used disinfection practice is the use of $\mathrm{NaClO}$ with $50-150 \mathrm{mg} \mathrm{L}^{-1}$, which also has potential risks [21]. Different chemical alternatives to chlorine have been used, such as chlorine dioxide, and acidified sodium chlorite. Moreover, other substances have been used for the same purpose, such as ozone, organic acids, peroxyacetic acid, hydrogen peroxide, electrolyzed water, and calcium-based solutions [21-26].

Physical alternatives, such as ultraviolet light $C$, low-temperature storage, modification of atmosphere, and ultrasound or high pressure inert gas, to maintain quality and prolong shelf- life, have also been used [4]. As the cutting operations are unavoidable for fresh-cut fruits and vegetables, 
and the risk of microbial growth is possible, the avoidance of food-borne pathogen contamination is necessary without the production of potentially toxic substances. Nowadays, chemical compounds that are used for fresh-cut fruit and vegetable preservation are not preferable for consumers when they are eating fresh-cut fruits and vegetables, as they prefer healthier, more natural, safer, and non-chemically contaminated foods [6].

Food preservation with the help of natural antimicrobial agents could be a very promising technique, playing an important role in maintaining food quality and safety [27]. Food biopreservation is an alternative and novel method of preservation with increasing special interest from the consumers $[22,28]$. Biopreservation can extend the shelf life of fresh-cut fruits and vegetables by the use of safe, natural, or controlled microflora, and non-toxic biologically active compounds [29], enhancing their safety [30]. Biopreservation can help the production of fresh-cut fruits and vegetables, with increased safety, excellent nutrition, overall quality, and improved shelf life through the use of lactic acid bacteria (LAB).

In the present review, recent developments in novel shelf life extension technologies applied to fresh and minimally processed fruits and vegetables - in order to maintain or improve the quality and safety of them (with the use of LAB as a biopreservation method)—will be discussed.

\section{Lactic Acid Bacteria}

The use of LAB play a dominant role in the fermentation of both food and feed [31], with health and nutritional benefits, and a very long history and safe use after consumption of fermented foods and beverages [32]. Taste and texture are the main (quality) characteristics of fermented foods that are enhanced with the addition of LAB [33]. Dairy products, fermented fruits and vegetables, meat-based products, and fermented beverages are the main fermented foods that involve LAB [34-36]. LAB exists in environments such as water, soil, sewage, plants, as well as in humans and animals [32]. In general, environments rich in available carbohydrates are ideal for the growth of LAB. Cavities of humans and animals are also favorable places for their growth [34]. LAB can be isolated from many raw fruits and vegetables, and then used against natural microbial populations [37].

LAB belong to different taxonomic groups of Gram-positive bacteria, with a common characteristic that produces lactic acid as the main (or sole) product during fermentation of carbohydrates [38,39]. They have rod- or coccus-shaped cells [40], do not form spores, and are anaerobic or microaerophilic and acid-tolerant organisms [41]. They are naturally present in several food products, from which can be isolated [42].

LAB are generally regarded as safe (GRAS) microorganisms by the United States Food and Drug Administration (FDA), and Qualified Presumption of Safety (QPS) by the European Food Safety Authority (EFSA). Their use in food biopreservation are considered an alternative for the prevention of the growth of pathogenic microorganisms [43,44], as their competitiveness against pathogenic microorganisms make them extremely ideal candidates for the development of bioprotective agents for fresh fruits and vegetables [45]. During biopreservation, either antimicrobial metabolites can be applied without the producing strain, or culture-producing antimicrobial metabolites can be added [46]. These starter cultures can be added, either as individual cultures or as multi-species consortia [47]. In the group of LAB bacteria, there are 6 families, 38 genera, and all belong to the Lactobacillales order, Bacilli class, and Firmicutes phylum.

Lactococcus, Streptococcus, Lactobacillus, Pediococcus, Leuconostoc, Lactosphaera, Melissococcus, Microbacterium Propionibacterium, Enterococcus, Carnobacterium, Tetragenococcus, Aerococcus, Alloiococcus Oenococcus, Vagococcus, Dolosigranulum, and Weisella are the most common genera that belong to LAB [48-51]. Among all the genes present in LAB, Lactobacillus consists of 261 species (March 2020), ranking it in the genus with the most members. The genus Lactobacillus has been reclassified into 25 genera, including the Lactobacillus delbrueckii group, Paralactobacillus, and 23 novel genera with the names Holzapfelia, Amylolactobacillus, Bombilactobacillus, Companilactobacillus, Lapidilactobacillus, Agrilactobacillus, Schleiferilactobacillus, 
Loigolactobacilus, Lacticaseibacillus, Latilactobacillus, Dellaglioa, Liquorilactobacillus, Ligilactobacillus, Lactiplantibacillus, Furfurilactobacillus, Paucilactobacillus, Limosilactobacillus, Fructilactobacillus, Acetilactobacillus, Apilactobacillus, Levilactobacillus, Secundilactobacillus and Lentilactobacillus [52]. The following are the most common species: Lactobacillus acidophilus, L. plantarum, L. Casei, L. rhamnosus, L. delbrueckii bulgaricus, L. fermentum, L. reuteri, Lactococcus lactis, Lactococcus lactis cremoris, Bifidobacterium bifidum, B. infantis, B. adolecentis, B. longum, B. breve, Enterococcus faecalis, Enterococcus faecium [51].

LAB produce a variety of antimicrobial compounds, such as organic acids (lactic, citric, acetic, fumaric, and malic acid), hydrogen peroxide, $\mathrm{CO}_{2}$, diacetyl, ethanol, reuterin, acetaldehyde, acetoin, ammonia, bacteriocins, bacteriocin-like inhibitory substances (BLIS), and other important metabolites, which possess strong antagonistic activity against many microorganisms [53-56] (Figure 1). In addition, the antimicrobial effect of lactic acid bacteria is the result of competition with pathogenic microorganisms for nutrients [24].

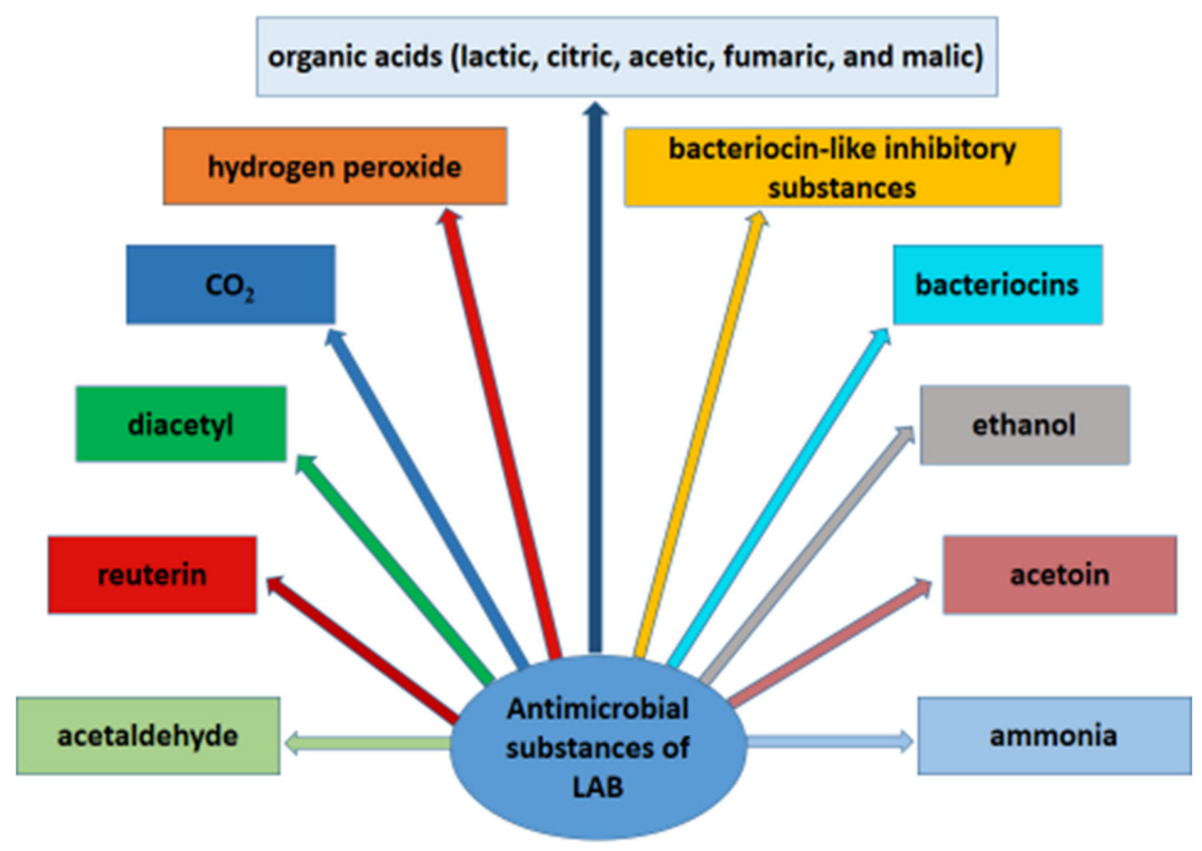

Figure 1. Antimicrobial substances produced by lactic acid bacteria.

Additionally, health-promoting properties have been linked with the presence of some strains of LAB and probiotics [57-59] as they have managed to reduce the risk of various diseases [60]. Probiotics have been identified as living microorganisms that have beneficial effects for humans and animals after adequate intake [61]. Probiotics have been used to prevent colon cancer [62], antibiotic-associated diarrhea, cholesterol reduction, lactose digestion [59], inflammatory bowel disease, breast cancer, and ulcerative colitis [63]. The genus Lactobacillus is one of the most widely used probiotics available on the market [60]. Probiotic bacteria do not live apart from the environment, but interact with the host, forming cooperative communities called biofilms [62].

In exception for their antimicrobial activity, LAB also have antifungal activity, which is of great interest, both against mycotoxigenic fungi and fungal mycotoxins, showing their potential by inactivation, removal, or detoxification processes [64-66]. The antifungal activity of LAB has prolonged the shelf life of fresh vegetables [67] and fruits [68].

\section{Foodborne Pathogens on Fresh and Minimally Processed Fruits and Vegetables}

Pathogenic microorganisms can infect fresh fruits and vegetables throughout the production process, starting from the soil, inadequately composted manure, contaminated seeds, contaminated water, and ending up to the foodstuff handlers, such as farmers, consumers, and kitchen 
workers-particularly the workers' hands [69]. In Figure 2, all of the basic routes of contamination, of fresh produce by foodborne pathogens, are presented.

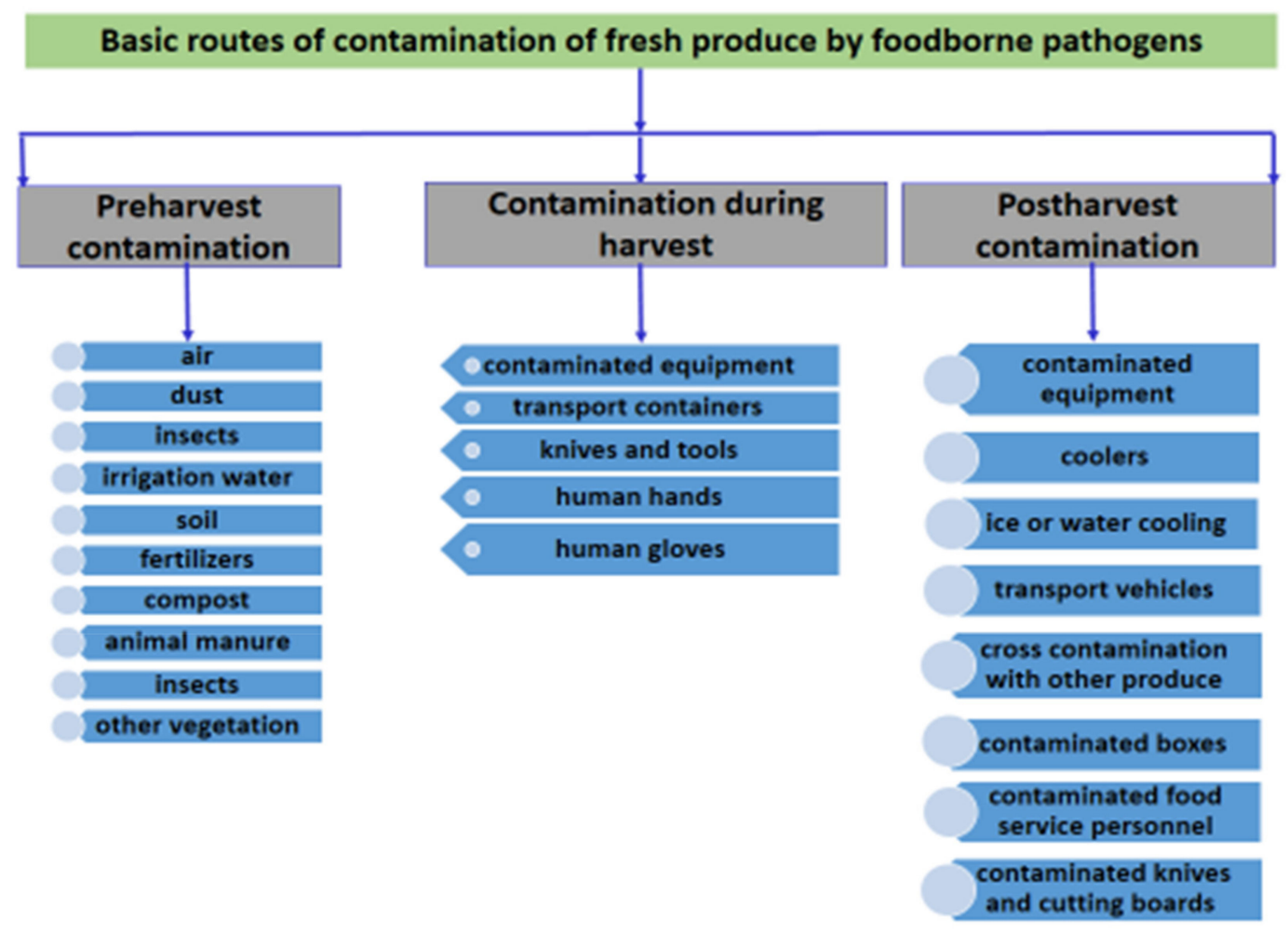

Figure 2. Basic routes of contamination of fresh produce by foodborne pathogens.

Escherichia coli O157:H7, Salmonella spp. [21], and Listeria monocytogenes are the main foodborne pathogens that exist on the surface of cut fruits and vegetables, causing serious damage to human health $[18,70]$. Outbreaks of these bacteria have been associated with fresh produce worldwide. In the U.S., most of these are linked with apples, stone fruits, mangos, blueberries, and papayas [71-76]. A recent outbreak was reported in 2019; it was associated with a Salmonella infection and linked to pre-cut melons [77]. Bacteria, such as Aeromonas hydrophila, Bacillus cereus, Clostridium spp., Shigella spp., Vibrio cholerae, Campylobacter spp., and Yersinia enterocolitica, have also been associated with high risk of illness outbreaks after people ate fresh and minimally processed fruits and vegetables, which has raised great concern [78]. In addition, parasites (Cryptosporidium, Cyclospora, helminths) and viruses (hepatitis A, noroviruses) are also a source of danger [79]. Table 1 presents some recent outbreaks associated with foodborne pathogens in fresh produce.

Salmonella bacteria are Gram-negative and can survive in a variety of conditions, with an optimum of $37^{\circ} \mathrm{C}$, a pH of $6.5-7.0$, and a water activity of less than $0.94[80,81]$, causing significant public health burdens in many countries. Salmonellosis is a foodborne disease, mainly caused by several non-typhoidal Salmonella enterica serovars, primarily the serovars Enteritidis and Typhimurium [82].

Salmonella spp. usually causes nausea, vomiting, abdominal pain, diarrhea, fever, and enterocolitis as main symptoms (after the consumption of contaminated foods) [83]. More than one million annual foodborne infections in the United States are caused by Salmonella spp., representing one third of all annual reported foodborne bacterial infections [84]. Reports show that Salmonella spp. is the most common bacterial pathogen responsible for fresh produce-associated disease outbreaks in developed countries, accounting for at least half of these outbreaks in the European Union (50\%) [85].

The biofilms formed by many strains of the Salmonella spp. on various processing-related surfaces, such as glasses, plastics, wood, and metals, may cause the so-called cross-contamination in different 
vegetables [86]. The biofilm functions as a survival mechanism as it helps microorganisms propagate in the environment, and to resist antimicrobial and sanitizing agents. Polysaccharides, proteins, lipids, and extracellular DNA are the main components of the biofilm. In exception, food biofilms can be found on moist surfaces, water pipelines, and pathological human tissues and organs [87].

According to an EFSA summary report, in 2016, salmonellosis was classified as a foodborne infection, with the highest incidences in the European Union (EU) when compared to other foodborne illnesses [88].

Table 1. Recent outbreaks associated with foodborne pathogens in fresh produce.

\begin{tabular}{|c|c|c|c|c|c|c|c|c|}
\hline $\begin{array}{l}\text { Food } \\
\text { Matrix }\end{array}$ & Pathogens & $\begin{array}{c}\text { Reported } \\
\text { Cases }\end{array}$ & Hospitalizations & Region & Deaths & Recall & Year & Reference \\
\hline Cut fruits & $\begin{array}{l}\text { Salmonella } \\
\text { Javiana }\end{array}$ & 165 & 73 & $\begin{array}{l}14 \text { states } \\
\text { of USA }\end{array}$ & - & Yes & 2020 & [89] \\
\hline $\begin{array}{l}\text { Pre-cut } \\
\text { melons }\end{array}$ & $\begin{array}{l}\text { Salmonella } \\
\text { Carrau }\end{array}$ & 137 & 38 & $\begin{array}{l}9 \text { states } \\
\text { of USA }\end{array}$ & - & Yes & 2019 & [77] \\
\hline $\begin{array}{c}\text { Fresh } \\
\text { papayas }\end{array}$ & $\begin{array}{l}\text { Salmonella } \\
\text { Uganda }\end{array}$ & 81 & 27 & $\begin{array}{l}9 \text { states } \\
\text { of USA }\end{array}$ & - & No & 2019 & [90] \\
\hline Cucumbers & $\begin{array}{l}\text { Salmonella } \\
\text { Poona }\end{array}$ & 907 & 204 & $\begin{array}{l}40 \text { states } \\
\text { of USA }\end{array}$ & 6 & Yes & 2016 & [91] \\
\hline Mushrooms & $\begin{array}{c}\text { Listeria } \\
\text { monocytogenes }\end{array}$ & 36 & 30 & $\begin{array}{l}17 \text { states } \\
\text { of USA }\end{array}$ & 4 & Yes & 2020 & [92] \\
\hline Cantaloupes & $\begin{array}{c}\text { Listeria } \\
\text { monocytogenes }\end{array}$ & 147 & 143 & $\begin{array}{l}28 \text { states } \\
\text { of USA }\end{array}$ & 33 & Yes & 2012 & [93] \\
\hline $\begin{array}{l}\text { Romaine } \\
\text { lettuces }\end{array}$ & $\begin{array}{c}\text { Escherichia coli } \\
\text { O157:H7 }\end{array}$ & 167 & 85 & $\begin{array}{l}27 \text { states } \\
\text { of USA }\end{array}$ & - & Yes & 2020 & [94] \\
\hline $\begin{array}{l}\text { Romaine } \\
\text { lettuces }\end{array}$ & $\begin{array}{c}\text { Escherichia coli } \\
\text { O157:H7 }\end{array}$ & 210 & 96 & $\begin{array}{l}36 \text { states } \\
\text { of USA }\end{array}$ & 5 & No & 2018 & [95] \\
\hline $\begin{array}{l}\text { Leafy } \\
\text { greens }\end{array}$ & $\begin{array}{c}\text { Escherichia coli } \\
\text { O157:H7 }\end{array}$ & 25 & 9 & $\begin{array}{l}15 \text { states } \\
\text { of USA }\end{array}$ & 1 & No & 2018 & [96] \\
\hline
\end{tabular}

The detection of Salmonella spp. in fresh-cut cabbage, sprouts, melons, cucumber, lettuces, tomatoes, carrots, and other raw fruits and vegetables, raises concerns about safety of consumption and consumer health. In addition, Salmonella Enteritidis was shown to be able to survive at $5^{\circ} \mathrm{C}$ and grow at 10 and $20{ }^{\circ} \mathrm{C}$ in Red Delicious apple flesh [70].

E. coli is Gram-negative and causes intestinal infections and extra-intestinal illnesses, both in humans and animals, having diarrhea as a basic symptom [71,97]. Sprouts, lettuce, and spinach are the most associated vegetables with contamination from E. coli. The strain E. coli O157: H7 was the first reported as enterohemorrhagic, having the ability of production of Shiga-like toxins [98]. E. coli O157: H7 can survive and grow, both in fresh fruits [70] and in fresh leafy green vegetables [98]. In the U.S., the most serious outbreak of E. coli O157: H7 associated with vegetables was recorded in 2018, when 5 of 210 patients died after consuming romaine lettuce [95]. In the European Union, one of the largest reported outbreaks of E. coli O104: H4 associated with sprouted seeds occurred in Germany and France (in 2011), with 3831 cases and 54 deaths [99].

Listeria are Gram-positive anaerobic bacteria that are ubiquitously found in nature. L. monocytogenes is the only bacterium that can cause human listeriosis through food consumption [43]. A century has passed since the 1920s, when listeriosis of humans and animals was first described as an infection [100]. As its occurrence in vegetables can reach $25 \%$, it causes concern in human health due to the fact that these products are consumed raw, with the proven growth of L. monocytogenes under refrigerated and ambient conditions [43]. Severe symptoms and high fatality rates may occur in people with weak immune systems, neonates, and pregnant women [101,102]. According to the EFSA, in 2019 it was reported that L. monocytogenes caused 229 deaths out of 2549 confirmed cases in 2018 . The category "vegetable and juices and other products thereof" was the food vehicle category with the higher percentage of listeriosis outbreak (28.6\%), indicating that the category of food is an important source of human infection [103]. L. monocytogenes can survive in extreme conditions, such as in cold, humid, and low 
oxygen environments, and it has been isolated from a variety of raw fruits and vegetables $[70,104]$. Apples and stone fruits are some of the fruits with high incidences of L. monocytogenes [105].

\section{Antimicrobial Effects of Lactic Acid Bacteria in Fresh and Minimally Processed Fruits and Vegetables}

In recent years, there has been a trend towards using biological methods to reduce the contamination of fresh fruits and vegetables to pathogens. Therefore, bioprotective agents have been used to inhibit the growth of pathogens [106]. Except from antimicrobial compounds, the microbial polysaccharides produced by LAB also have shown significant antibacterial activity against pathogens, such as E. coli, L. monocytogenes, Salmonella Typhimurium and Shigella sonnei [107].

LAB belong to the most promising biocontrol agents for improving shelf life of fresh-cut fruits and vegetables. Although the shelf life of fresh fruits and vegetables can last a few weeks, this cannot happen with fresh-cut fruits and vegetables that are only kept for 4 to 10 days, under refrigerated conditions, due to the possible growth of pathogenic microorganisms [24].

The use of LAB in the biopreservation of fresh fruits and vegetables can also be enhanced when combined with other storage methods. Low oxygen modified atmosphere packaging is one of the well reported methods that is applied in storage for fresh produce for extending shelf life [108]. The combination of Lactobacillus plantarum subsp. plantarum CICC 6257 with low oxygen modified atmosphere packaging technology has been successfully used for the reduction of pathogenic potential of L. monocytogenes in cabbages, according to a recent study by Dong et al. [109].

Vescovo et al. [110] and Torriani et al. [111] first used the Lactobacillus casei, or their culture filtrate to control pathogenic microorganisms in ready-to-use vegetables, and highlighted their inhibitory effects. The addition of 3\% culture permeate of L. casei IMPC LC34 to mixed salads was, according to Torriani et al. [111], reported to cause a decrease in the total mesophilic bacteria counts from 6 to $1 \log$ colony forming units (CFU)/g and to suppress coliforms, enterococci, and A. hydrophila after 6 days of storage at $8{ }^{\circ} \mathrm{C}$. In another study, the inhibitory activity of some lactic acid bacteria was evaluated against foodborne human pathogens. Strains of Leuconostoc spp., Lactobacillus plantarum, Weissella spp., and Lactococcus lactis were isolated from fresh fruits and vegetables and they were inoculated on wounded Golden Delicious apples and Iceberg lettuce cut leaves. The results showed the total inhibition of $L$. monocytogenes and the reduction in population of $S$. Typhimurium and E. coli by 1 to $2 \log$ CFU/wound or g [19].

The enrichment of minimally processed yellow melon by Lactobacillus rhamnosus HN001 and the correlation between microbiological characteristics was evaluated by Martins de Oliveira et al. [13]. The results from this study demonstrated high viability of Lactobacillus rhamnosus HN001, as there were high adhesion of L. rhamnosus HN001 on the vegetal tissue; microbiological safety as Salmonella sp. was not detected in any sample, giving a healthy, transformed probiotic food. In a more recent study, bacterium suspension belonging to L. plantarum was sprayed in fresh lotus roots in order to limit the oxidation of phenolic compounds that are responsible for enzymatic browning reaction, and to evaluate the postharvest properties of this vegetable. The L. plantarum suspension proved capable of causing an $84.17 \%$ transformation of catechin after interaction for $30 \mathrm{~h}$ with plant skin. Texture characteristics, such as hardness, chewiness value, springiness, and cohesiveness, also significantly improved, proving that the use of lactic acid bacteria have contributed to the extension of shelf life of fresh lotus roots [112].

Lokerse et al. studied the development of L. monocytogenes in the ingredients of fresh-cut salads by determining the effect of product characteristics and the presence of competitive flora, especially LAB. Most of the products tested did not have the presence of L. monocytogenes greater than $3.4 \log \mathrm{CFU} / \mathrm{g}$, and only the Galia melon exceeded $3.4 \log \mathrm{CFU} / \mathrm{g}$, indicating that the Galia melon, which is often used in fruit salads, is the main ingredient that can contribute to the development of L. monocytogenes. Inhibition of the growth of L. monocytogenes was achieved in some components of fruit salads, such as non-pasteurized potatoes, white cabbage, and mango containing a high number of LAB [101]. 
Recently, Ramos et al. (2020) developed an alternative biopreservation approach to maintain the safety of fresh lettuce, rocket salad, parsley, and spinach. As a protective culture against L. monocytogenes, they examined the potential of bacteriocinogenic LAB, Pediococcus pentosaceus DT016 during preservation. In vegetables inoculated with P. pentosaceus DT016, the number of pathogens were significantly lower $(p<0.01)$, and only at the last day of storage, a minimal difference of $1.4 \log$ $\mathrm{CFU} / \mathrm{g}$ was observed compared to vegetables without protective culture [43]. Antagonistic effect of Pseudomonas graminis CPA-7 against two foodborne pathogens (Salmonella spp. and L. monocytogenes) was recorded in fresh-cut apples [113] and melons [114].

In Table 2, studies with LAB and biopreservation of fresh and minimally processed fruits and vegetables are presented. 
Table 2. Lactic acid bacteria and biopreservation of fresh and minimally processed fruits and vegetables.

\begin{tabular}{|c|c|c|c|c|c|}
\hline Food Matrix & Lactic Acid Bacteria & $\begin{array}{c}\text { Target Pathogen or } \\
\text { Postharvest Properties }\end{array}$ & Process Duration & Effect & Reference \\
\hline Fresh-cut pear & Lactobacillus rhamnosus GG & $\begin{array}{l}\text { Salmonella spp. and } \\
\text { L. monocytogenes }\end{array}$ & 9 days & $\begin{array}{l}\text { Reduction on Salmonella spp. } \\
\text { population, no effect in } \\
\text { L. monocytogenes }\end{array}$ & [115] \\
\hline Lamb's lettuce & $\begin{array}{l}\text { Lactobacillus plantarum, } \\
\text { Lactobacillus casei }\end{array}$ & E. coli and L. monocytogenes & 16 days & $\begin{array}{l}\text { Significant inhibition of E. coli and } \\
\text { L. monocytogenes }\end{array}$ & [20] \\
\hline Sliced apples & Lactobacillus plantarum & & & & \\
\hline \multirow[t]{2}{*}{ Table grapes } & $\begin{array}{c}\text { Lactobacillus delbrueckii subsp. } \\
\text { bulgaricus strain F17 }\end{array}$ & \multirow{2}{*}{$\begin{array}{l}\text { Aerobic mesophilic bacteria, } \\
\text { yeast and molds, and coliform } \\
\text { bacteria }^{{ }^{a}}\end{array}$} & \multirow[t]{2}{*}{20 days } & \multirow{2}{*}{$\begin{array}{l}\text { Significant inhibition during the } \\
\text { storage period and improvement in } \\
\text { the postharvest quality }\end{array}$} & \multirow[t]{2}{*}{ [116] } \\
\hline & Leuconostoc lactis strain H52 & & & & \\
\hline $\begin{array}{l}\text { Fresh-cut curly leafy } \\
\text { greens }\end{array}$ & Lactobacillus curvatus & L. monocytogenes & 8 days & Reduction of L. monocytogenes & [102] \\
\hline Fresh-cut fruit mixture & Lactobacillus pentosus MS031 & $\begin{array}{l}\text { L. monocytogenes, E. coli, } \\
\text { S. aureus }\end{array}$ & 10 days & $\begin{array}{l}\text { Reduction } 96.3 \% \text { of } \\
\text { L. monocytogenes, undetectable level } \\
\text { for E. coli, S. aureus }\end{array}$ & [117] \\
\hline Fresh-cut cantaloupe & $\begin{array}{c}\text { Lactobacillus plantarum B2, } \\
\text { Lactobacillus fermentum } \\
\text { PBCC11.5 }\end{array}$ & L. monocytogenes & 11 days & Reduction of L. monocytogenes & [118] \\
\hline Lotus root & $\begin{array}{l}\text { Lactobacillus plantarum } \\
\text { (LH-B02) }\end{array}$ & Postharvest properties & 15 days & $\begin{array}{l}\text { Reduction of color loss } \\
\text { enhancement of elasticity, } \\
\text { coherence }\end{array}$ & [112] \\
\hline Litchi & Lactobacillus plantarum & Postharvest properties & 21 days & $\begin{array}{l}\text { Reduction of browning, reduction } \\
\text { of color loss, high concentration of } \\
\text { phenolic compounds }\end{array}$ & [119] \\
\hline Mixed salads & Lactobacillus casei & $\begin{array}{l}\text { Coliforms, enterococci, } \\
\text { and Aeromonas hydrophila }\end{array}$ & 6 days & $\begin{array}{c}\text { Reduction in the total number of } \\
\text { mesophilic bacteria, suppression of } \\
\text { coliform bacteria, enterococci and } \\
\text { Aeromonas hydrophila }\end{array}$ & [110] \\
\hline
\end{tabular}

${ }^{a}$ Not determined in the Publication. 


\section{Antimicrobial Effects of Metabolites of Lactic Acid Bacteria in Fresh and Minimally Processed Fruit and Vegetables}

\subsection{Bacteriocins}

Bacteria (Gram-positive and Gram-negative) produce several interesting substances of protein structure, with bactericidal or bacteriostatic action, called bacteriocins, which act competitively for the same ecological position, or nutrient pool, with closely related microorganisms, and mainly with Gram-positive bacteria [120-122]. These substances are used by bacteria as a defense against other threatening microorganisms [123]. Anti-viral and anti-fungal properties can also be caused by some bacteriocins [124]. Bacteriocins are different from antibiotics, as they are produced during the lag phase and are classified as primary metabolites, while antibiotics are produced after the end of microbial growth and are classified as secondary metabolites [125]. There are two different types of bacteriocins, according to their inhibitory spectrum. In the first type, bacteriocins exert their inhibitory activity against bacteria of the same species with the bacteriocin producing bacterium; they are called narrow spectrum bacteriocins. In the second type, bacteriocins exert their inhibitory activity against bacteria of different genera; they are called broad-spectrum bacteriocins [124]. A bacteriocin is considered ideal when small concentrations are required to act, has a wide range of action against several pathogenic microorganisms, does not cause any damage to the product that is applied, and there is no high cost for its production [126].

Bacteriocins produced by LAB, are antimicrobial peptides, containing about 30-60 amino acids, with small molecular weight that can be used as natural and safe food preservatives in a variety of foods, including fruits and vegetables, without altering the nutritional and sensorial properties or the physicochemical characteristics of the food $[49,104]$. There are also bacteriocins that are larger in size and are described as proteins [127]. They are ribosomally synthesized peptides; they have different structure and biochemical properties. Moreover, they are differentiated both in the mode of action and spectrum of activity $[128,129]$, in size, and in specificity [126]. Preservation with bacteriocins belong to the non-thermal preservation method [130]. There are many bacteriocins, such as nisin, enterocin AS-48 and 416K1, bovicin HC5, enterocin 416K1, bificin C6165, and pediocin, which have been described and tested in the preservation of quality in fresh fruits and vegetables $[28,129]$. The mechanism by which antimicrobial activity is performed is relatively complicated, and for each bacteriocin and food, different types of interactions are created [131]. Bacteriocins act against the bacterial cytoplasmic membrane by disrupting the movement of protons [49], causing the leakage of ions, ATP, RNA or DNA molecules and the cellular death of spoiling and pathogenic microorganisms [132].

Bacteriocins have poor efficiency towards Gram-negative bacteria, as this group of bacteria have an outer membrane, which acts as an efficient permeability barrier [133]. This membrane prevents the passage of molecules, including antimicrobials agents [134]. Moreover, the efficacy of bacteriocins against Gram-negative bacteria can be enhanced by the addition of chelating agents (e.g., EDTA) or hydrostatic pressure [120,135]. Bacteriocins are active in the nanomolar range [128]; they have high-temperature stability [136] and, until 2017, had quantified a total of 785 bacteriocins from LAB [38]. Various factors affect the production of bacteriocins, including environmental factors, temperature, and $\mathrm{pH}$. Temperature $30-37^{\circ} \mathrm{C}$ and $\mathrm{pH} 5.0-8.0$ are the optimum conditions in which bacteriocins are usually developed $[123,128]$. The reduced effectiveness of bacteriocins can be attributed to the development of resistance by certain pathogenic microorganisms, to their interaction, inactivation, or even to their binding to a variety of food ingredients, as well as to their random distribution in the food [137]. Bacteriocins act against a limited number of target-bacteria (which usually have the same needs) and this is the main disadvantage of these antimicrobial substances [138].

From the first classification of bacteriocins in 1993 by Klaenhammer [139], many classifications have been mediated. One of the last classifications has been made by Alvarez-Sieiro et al. in 2016. This classification was based on the biosynthesis mechanism, genetics, and structure; according to it, bacteriocins were classified into three classes, heat stable $(<10 \mathrm{kDa})$ Class I, and Class II, 
and thermolabile ( $>10 \mathrm{kDa}$ ) Class III [38]. Class I bacteriocins, Class II bacteriocins, and Class III bacteriocins are also called lantibiotics [134], non-lantibiotics, or pediocin-like antibiotics, and are sensitive to heat, respectively $[140,141]$.

The use of bacteriocins as an alternative method of preserving fruits and vegetables is under investigation, although the bacteriocins have the properties to be used for their preservation. To date, only nisin (marketed as Nisaplin and other brand names) and pediocin PA-1/AcH and Micocinßhave been approved for use as food additives by the FDA. Although their use has not been formally approved in fruits and vegetables, many studies have evaluated their use in fruits and vegetables as they act as natural antimicrobials and alternatives to chemical food preservatives [129,142]. In fact, an indirect way of introducing bacteriocins into foods is being implemented, so that producer strains can be inoculated to fresh produce, to produce bacteriocins in situ [38]. Moreover, bacteriocins can be added directly to fruits and vegetables, acting as food additives, which increases their microbiological safety [143].

Dhundale et al. (2018) examined the use of bacteriocinogenic lactic acid bacteria (BLAB) for biopreservation of fruits. Bacterial-producing LABs were isolated from curd and cow dung samples and were tested on 25 isolated bacterial fruit flora from apple, fig, banana, sapodilla, kiwi, strawberry, and pomegranate. The BLAB coating forms a film on the surface of the fruit; thus, inhibiting the bacteria that destroy the fruit. The antibacterial activity against the fruit flora, as well as the pathogenic microorganisms E. coli, Staphylococcus aureus, Bacillus cereus, Pseudomonas aeroginosa, Proteus vulgaris, Salmonella typhi, Serritia spp, Xanthomonas campestris, make the use of BLAB a bioproduct capable of prolonging fruit life [144]. Table 3 presents studies on the biopreservation of fresh and minimally processed fruits and vegetables with the use of bacteriocins. 
Table 3. Bacteriocins and biopreservation of fresh and minimally processed fruits and vegetables.

\begin{tabular}{|c|c|c|c|c|c|}
\hline Food Matrix & Bacteriocins & Target Pathogen & Process Duration & Effect & Reference \\
\hline Fresh-cut leafy greens & Pediocin DT016 & L. monocytogenes & 15 days & Significant inhibition of L. monocytogenes & [43] \\
\hline Fresh-cut lettuce & $\begin{array}{c}\text { Pseudomonas graminis CPA-7 and } \\
\text { nisin }\end{array}$ & L. monocytogenes & 6 days & Reduction of L. monocytogenes & [106] \\
\hline Fresh-cut lettuce & Bacteriocin & L. monocytogenes & 6 days & Reduction of L. monocytogenes & [30] \\
\hline Cabbage & $\begin{array}{l}\text { Crude bacteriocin extracts from } \\
\text { the Lactobacillus species }\end{array}$ & S. aureus, E. coli, and Shigella species & 3 days & $\begin{array}{c}\text { Inhibitory activity against } S . \text { aureus, E. coli, } \\
\text { and Shigella species }\end{array}$ & [142] \\
\hline Fresh-cut iceberg lettuce & Nisin A & L. monocytogenes & 7 days & $\begin{array}{l}\text { 100-fold reduction of L. monocytogenes, } \\
\text { extend the shelf life }\end{array}$ & [145] \\
\hline $\begin{array}{l}\text { Fresh strawberries, } \\
\text { tomatoes and mushrooms }\end{array}$ & $\begin{array}{l}\text { Bacteriocin, producing by } \\
\text { Pediococcus spp. }\end{array}$ & E. coli and Shigella spp. & 15 days & $\begin{array}{l}\text { Increased shelf life and enhanced } \\
\text { microbiological quality }\end{array}$ & [146] \\
\hline Potatoes & Nisin-formic acid combination & Bacillus subtilis & 10 days & $\begin{array}{l}\text { Inactivation of the proliferation of Bacillus } \\
\text { subtilis }\end{array}$ & [147] \\
\hline Bananas & $\begin{array}{l}\text { Enterocin KT2W2G-cinnamon oil } \\
\text { combination }\end{array}$ & $\begin{array}{l}\text { Klebsiella variicola, Serratia } \\
\text { marcescens, Lactococcus lactis subsp. } \\
\text { Lactis, Klebsiella pneumoniae } \\
\text { Enterococcus faecalis }\end{array}$ & a & $\begin{array}{l}\text { Inhibition spoilage bacteria and extension } \\
\text { the shelf life of bananas }\end{array}$ & [148] \\
\hline Fresh-cut melon & Nisin & E.coli O157:H7, L. monocytogenes & 7 days & $\begin{array}{l}\text { Reduction E.coli O157:H7 and } \\
\text { L. monocytogenes }\end{array}$ & [149] \\
\hline Fresh-cut lettuce & $\begin{array}{l}\text { Nisin, coagulin and a cocktail of } \\
\text { both bacteriocins }\end{array}$ & L. monocytogenes & 7 days & Decrease in the viability of L. monocytogenes & [150] \\
\hline Fresh fruits & Enterocin AS-48 & L. monocytogenes & 7 days & $\begin{array}{l}\text { Significant inhibition or completely } \\
\text { inactivation of L. monocytogenes }\end{array}$ & [151] \\
\hline
\end{tabular}

${ }^{a}$ Not determined in the Publication. 


\subsection{Nisin}

Nisin is the most studied and applied bacteriocin and has been characterized as GRAS by the Food and Agriculture Organization (FAO) of the United Nations, the World Health Organization (WHO), and the FDA. In addition, the use of nisin in certain foods is authorized as a preservative additive (E-234) in the European Union (EU) [152]. Nissin was the first commercially used bacteriocin since 1969. The lethal dose $\left(\mathrm{LD}_{50}\right)$ has been estimated as $6950 \mathrm{mg} / \mathrm{kg}$, which means that there are no toxic effects on humans [153]. In context of the GRAS status, the maximum allowable dose of nisin that can be used is $250 \mathrm{ppm}$ [154]. The combined action of nisin with various organic acids could contribute to increasing its inhibitory effect against various Gram-positive bacteria that have developed resistance to this bacteriocin [155]. Nowadays, its use as a bioprotective agent in the food industry has been allowed in more than 50 countries worldwide [156]. Nisin is effective, mainly against Gram-positive foodborne pathogens or spoilage bacteria, such as S. aureus, L. monocytogenes, A. acidoterrestris, Clostridium, and Bacillus spores $[129,157]$. Except for the antibacterial ability of nisin, it has been proven that nisin has positive effects in the maintenance of vitamin $C$, in minimally processed mangoes, meaning that nisin can help in the quality of this fruit [158].

Nisin is a hydrophobic and cationic protein. It has low molecular weight (3353 Da), and is found in several types, such as, nisin A, nisin U, nisin Z, etc. Every type has different antimicrobial activity spectrum, but all are produced by certain strains of Lactococcus lactis ssp. lactis [123].

The combination of nisin-producing Lactococcus lactis CBM21 with thyme essential oil showed good inhibitory effect against L. monocytogenes and E. coli when applied as washing solution in the lamb's lettuce without affecting their quality parameters [159].

\subsection{Pediocins}

Pediocins are produced mainly by strains of Pediococcus pentosaceus and Pediococcus acidilactici from the Pediococcus spp. genus [160]. Pediocins are basically characterized by their antilisterial activity [161,162]. Pediocin can be used in antimicrobial packaging, as it can be incorporated with films. Nanocomposite films with pediocin and $\mathrm{ZnO}$ nanoparticles presented antimicrobial activity against $S$. aureus and L. monocytogenes [163]. A pediocin DT016 solution was used to inactivate L. monocytogenes in fresh, leafy vegetables (lettuce, rocket salad, parsley, and spinach) during prolonged storage at $4{ }^{\circ} \mathrm{C}$. The results were compared with those of leafy vegetables washed with water and chlorine. In pediocin-washed vegetables, there was a significant reduction of pathogen proliferation, by 3.2 and $2.7 \log \mathrm{CFU} / \mathrm{g}$, compared with vegetables washed in water and chlorine, respectively [43].

\section{Edible Coatings and Films, and Lactic Acid Bacteria in Fresh and Minimally Processed Fruits and Vegetables}

The use of edible coatings and films in fresh-cut fruits and vegetables aims at maintaining the overall quality, as well as extending shelf life, as several active ingredients can be incorporated into these innovative and alternative materials, controlling basic functions, such as moisture transfer, gas exchange, and oxidation processes. Texture enhancers, antioxidants, nutrients, antimicrobial, and anti-browning agents can be added in fresh-cut fruits and vegetables, without affecting consumer acceptance, contributing significantly to quality improvement and safety [164].

The surface of minimally proceeded fruits and vegetables is undoubtedly the most contaminated part with foodborne pathogens. The use of bacteriocin-incorporated edible coatings and films could affect the quality and safety of these products, reducing the disadvantage of interacting with ingredients that fruits and vegetables have [129]. The incorporation of live microbial cells of LAB with edible coatings and films can affect some physical properties, such as barrier and mechanical, and can also bind the antimicrobial substances to the food product in order to maintain a proper cell concentration that will be able to exhibit an antimicrobial effect [165].

Edible coatings and films are an alternative approach to maintaining quality and extending the shelf life of fresh-cut fruits and vegetables, and partially prevent the colonization of the fruit by human 
pathogenic bacteria, leading to increased food safety $[166,167]$. Edible coatings and films added with bacteriocins are promising natural preservatives for reducing foodborne pathogens [129], and the way of application is very important. Between direct application of bacteriocin and its inclusion in an edible coating and film, the second option appears the most promising, as the release of antimicrobial agent is controlled and the stability of the antimicrobial agent is also increased [158].

In addition, the combination of bacteriocins with other antimicrobial substances or stressors have managed to increase their antimicrobial efficacy against spoiling and pathogenic microorganisms [156]. Edible antimicrobial coatings are consumed with the fruit or vegetable that they wrap, while at the same time, being natural barriers to gas exchange between fresh produce and the environment [168]. In addition, edible coatings and films can incorporate with bifidobacteria in order to increase the probiotics properties of fresh produce [169].

Tenea et al. (2020), in a very recent study, investigated the efficacy of peptide-based coatings from Lactobacillus plantarum UTNCys5-4 and Lactococcus lactis subsp. lactis Gt28 strains against a pathogenic cocktail containing E. coli, Salmonella and Shigella in fresh-cut slices of pineapple. The results, after 5 days preserved in refrigeration, showed a decrease in cell counts of $2.08 \log \mathrm{CFU} / \mathrm{g}, 1.43 \log$ $\mathrm{CFU} / \mathrm{g}$, and $1.91 \log \mathrm{CFU} / \mathrm{g}$ for the E. coli, Salmonella, and Shigella, respectively, indicating that these coatings are a good alternative to chemical compounds, increasing the shelf life and safety of fresh-cut pineapple [170]. Moreover, coatings with antimicrobial peptides from Lactobacillus plantarum UTNGt2 were used for inhibition of E. coli and Salmonella and the estimation of postharvest quality in fresh tomatoes. After 17 days of storage in room temperature, in the peptide-treated tomatoes, no external alteration was observed, and although no complete reduction of E. coli and Salmonella was observed, effective inhibition was demonstrated [171].

The enrichment of $0.5 \%$ carboxymethyl cellulose (CMC) edible coatings with bacteriocin from Bacillus methylotrophicus BM47 was studied by Tumbarski et al. (2019) in order to evaluate postharvest quality parameters and their efficacy of extending shelf life in fresh strawberries. Strawberries were preserved at $4{ }^{\circ} \mathrm{C}$ and relative humidity $75 \%$ for 16 days. The results were compared to CMC coated strawberries. The use of $\mathrm{CMC}$ with bacteriocin $(\mathrm{CMC}+\mathrm{B})$ coatings showed positive influence on antioxidant activity, improvement in commercial appearance, and in shelf life [28]. Table 4 presents studies on the biopreservation of fresh and minimally processed fruits and vegetables with the use of edible coatings and films. 
Table 4. Edible coatings and films and biopreservation of fresh and minimally processed fruits and vegetables.

\begin{tabular}{|c|c|c|c|c|c|}
\hline Food Matrix & Edible Coatings and Films & TARGET Pathogen & Process Duration & Effect $^{a}$ & Reference \\
\hline Fresh strawberries & $\begin{array}{l}\text { Bacillus methylotrophicus BM47 } \\
\text { incorporated into carboxymethyl } \\
\text { cellulose edible coatings }\end{array}$ & a & 16 days & $\begin{array}{l}\text { Inhibition of fungal growth, } \\
\text { improvement of shelf life }\end{array}$ & [28] \\
\hline $\begin{array}{l}\text { Minimally processed } \\
\text { mangoes }\end{array}$ & Nisin-incorporated cellulose films & L. monocytogenes & 12 days & Reduction L. monocytogenes by $1 \log$ & [158] \\
\hline Pineapple & $\begin{array}{l}\text { Lactobacillus plantarum UTNCys5-4 and } \\
\text { Lactococcus lactis subsp. lactis Gt28 }\end{array}$ & E. coli, Salmonella and Shigella & 5 days & $\begin{array}{l}\text { Reduction by } 2.08,1.43 \text {, and } 1.91 \mathrm{log} \\
\text { CFU/g, for E. coli, Salmonella, and Shigella } \\
\text { respectively }\end{array}$ & [170] \\
\hline Fresh tomatoes & Lactobacillus plantarum UTNGt2 coatings & E. coli and Salmonella & 17 days & Inhibition & [171] \\
\hline Fresh strawberries & $\begin{array}{l}\text { Lactobacillus plantarum incorporated into } \\
\text { carboxymethyl cellulose edible coatings }\end{array}$ & Yeast and molds & 15 days & $\begin{array}{c} \pm \text { color, hardness, TSS, TA, and total } \\
\text { anthocyanin—weight loss, decay Less } \\
\text { yeast and mold number }\end{array}$ & [172] \\
\hline Fresh blueberries & $\begin{array}{l}\text { Lactobacillus rhamnosus CECT } 8361 \\
\text { incorporated into alginate coatings }\end{array}$ & Listeria innocua, E. coli O157:H7 & 21 days & Reduction L. innocua counts by $1.7 \mathrm{log}$ & [173] \\
\hline $\begin{array}{l}\text { Minimally processed } \\
\text { papaya }\end{array}$ & $\begin{array}{l}\text { Pediocin produced from Pediococcus } \\
\text { pentosaceus incorporated alginate coating }\end{array}$ & Mesophilic bacteria and fungi & 21 days & $\begin{array}{c}\text { Inhibition of mesophilic bacteria and } \\
\text { fungi }\end{array}$ & {$[174]$} \\
\hline
\end{tabular}

${ }^{a}$ Not determined in the Publication. 


\section{Conclusions}

Foodborne pathogens are inevitable microorganisms found in fresh-cut fruits and vegetables, mainly associated with foodborne outbreaks, such as listeriosis and salmonellosis. Although chemical control of these pathogens is widely used in the industry, consumer demand for healthy, "more nature", and "free chemical" fresh produce has led the food industry to adopt biological control as an alternative technique to maintain safety and reduce contamination. Protective cultures of LAB and their metabolites play an important role in biocontrol, as their potential inhibitory effects against pathogens are well documented, without changing the sensory properties of foods. In particular, the use of primary metabolites, bacteriocins, both in situ after inoculation to the fresh produce, and by incorporation into edible coatings, is a simple and environmentally friendly biopreservation technique that does not require the use of expensive laboratory equipment. Moreover, the use of bacteriocins and edible films and coatings does not affect the organoleptic characteristics of fruits and vegetables and consumer acceptance. Additionally, as LAB can survive under cold storage temperatures, their metabolites can be used as food bioadditives in preservation of fresh-cut fruits and vegetables. Characteristics of the producer strain culture, such as technical effectiveness, commercial viability, the applied dose, and the complex mechanisms of action (including membrane permeabilization) are issues that need to be carefully addressed. As foods are complex matrices with varied components, the effectiveness of each biopreservative agent should be evaluated separately.

Author Contributions: Investigation, S.A.; resources, S.A., E.S., M.S.-K., and T.V.; Writing-Original draft preparation, S.A., E.S., M.S.-K., and T.V.; Writing-Review and editing, S.A., E.S., M.S.-K., and T.V.; supervision T.V. All authors have read and agreed to the published version of the manuscript.

Funding: This research received no external funding.

Conflicts of Interest: The authors declare no conflict of interest.

\section{References}

1. Berger, C.N.; Sodha, S.V.; Shaw, R.K.; Griffin, P.M.; Pink, D.; Hand, P.; Frankel, G. Fresh fruit and vegetables as vehicles for the transmission of human pathogens. Environ. Microbiol. 2010, 12, 2385-2397. [CrossRef] [PubMed]

2. Charlton, K.; Kowal, P.; Soriano, M.M.; Williams, S.; Banks, E.; Vo, K.; Byles, J. Fruit and vegetable intake and body mass index in a large sample of middle-aged Australian men and women. Nutrients 2014, 6, 2305-2319. [CrossRef] [PubMed]

3. More, A.S.; Ranadheera, C.S.; Fang, Z.; Warner, R.; Ajlouni, S. Biomarkers associated with quality and safety of fresh-cut produce. Food Biosci. 2020, 34, 100524. [CrossRef]

4. Leneveu-Jenvrin, Q.; Quentin, B.; Assemat, S.; Hoarau, M.; Meile, J.-C.; Remize, F. Changes of quality of minimally-processed pineapple (Ananas comosus, var. 'Queen Victoria') during cold storage: Fungi in the leading role. Microorganisms 2020, 8, 185. [CrossRef]

5. De Corato, U. Improving the shelf life and quality of fresh and minimally-processed fruits and vegetables for a modern food industry: A comprehensive critical review from the traditional technologies into the most promising advancements. Crit. Rev. Food Sci. Nutr. 2020, 6, 940-975. [CrossRef]

6. Hasan, S.M.K.; Ferrentino, G.; Scampicchio, M. Nanoemulsion as advanced edible coatings to preserve the quality of fresh-cut fruits and vegetables: A review. Int. J. Food Sci. Technol. 2020, 55, 1-10. [CrossRef]

7. Septembre-Malaterre, A.; Remize, F.; Poucheret, P. Fruits and vegetables, as a source of nutritional compounds and phytochemicals: Changes in bioactive compounds during lactic fermentation. Food Res. Int. 2018, 104, 86-99. [CrossRef]

8. El-Ramady, H.R.; Domokos-Szabolcsy, E.; Abdalla, N.A.; Taha, H.S.; Fari, M. Postharvest management of fruits and vegetables storage. In Sustainable Agriculture Reviews; Lichtfouse, E., Ed.; Springer International Publishing: Cham, Switzerland, 2015; pp. 65-152. 
9. U.S. Department of Health and Human Services; U.S. Department of Agriculture. 2015-2020 Dietary Guidelines for Americans, 8th ed.; U.S. Department of Health and Human Services: Washington, DC, USA; U.S. Department of Agriculture: Washington, DC, USA, 2015. Available online: http://health.gov/ dietaryguidelines/2015/guidelines/ (accessed on 12 May 2020).

10. IFPA (International Fresh-Cut Produce Association); PMA (The Produce Marketing Association). Handling Guidelines for the Fresh-Cut Produce Industry, 3rd ed.; IFPA: Alexandria, VA, USA, 1999; p. 5.

11. Corbo, M.R.; Campaniello, D.; Speranza, B.; Bevilacqua, A.; Sinigaglia, M. Non-conventional tools to preserve and prolong the quality of minimally-processed fruits and vegetables. Coatings 2015, 5, 931-961. [CrossRef]

12. Gross, K.C.; Wang, C.Y.; Saltveit, M. The Commercial Storage of Fruits, Vegetables, and Florist and Nursery Stocks. In United States Department of Agriculture (USDA)—Agricultural Research Service-Agriculture Handbook; $\mathrm{N}^{\mathrm{O}}$ 66; Gross, K.C., Wang, C.Y., Saltveit, M., Eds.; U.S. Department of Agriculture: Washington, DC, USA, 2016; p. 780. Available online: http://www.ars.usda.gov/is/np/indexpubs (accessed on 12 May 2020).

13. De Oliveira, P.M.; Leite Júnior, B.R.; Martins, M.L.; Martins, E.M.F.; Ramos, A.M. Minimally processed yellow melon enriched with probiotic bacteria. Semin. Agrar. 2014, 35, 2415-2426. [CrossRef]

14. Salazar, J.K.; Sahu, S.N.; Hildebrandt, I.M.; Zhang, L.; Qi, Y.; Liggans, G.; Datta, A.R.; Tortorello, M.L. Growth kinetics of listeria monocytogenes in cut produce. J. Food Prot. 2017, 80, 1328-1336. [CrossRef]

15. Ali, A.; Yeoh, W.K.; Forney, C.; Siddiqui, M.W. Advances in postharvest technologies to extend the storage life of minimally processed fruits and vegetables. Crit. Rev. Food Sci. Nutr. 2018, 58, 2632-2649. [CrossRef] [PubMed]

16. Manolopoulou, E.; Varzakas, T. Application of antibrowning agents in minimally processed cabbage. J. Food Nutr. Disord. 2014, 3, 2.

17. Varzakas, T.; Manolopoulou, E. Comparison of HACCP and ISO 22000 in the ready-to-eat fruit and vegetable industry in conjunction with application of failure mode and effect analysis (FMEA) and Ishikawa diagrams. In Minimally Processed and Refrigerated Fruits and Vegetables; Yildiz, F., Wiley, R.C., Eds.; Springer: Boston, MA, USA, 2017; pp. 685-721.

18. Qadri, O.S.; Yousuf, B.; Srivastava, A.K. Fresh-cut fruits and vegetables: Critical factors influencing microbiology and novel approaches to prevent microbial risks-A review. Cogent Food Agric. 2015, 1, 1121606. [CrossRef]

19. Trias, R.; Bañeras, L.; Badosa, E.; Montesinos, E. Bioprotection of Golden Delicious apples and Iceberg lettuce against foodborne bacterial pathogens by lactic acid bacteria. Int. J. Food Microbiol. 2008, 123, 50-60. [CrossRef] [PubMed]

20. Siroli, L.; Patrignani, F.; Serrazanetti, D.I.; Tabanelli, G.; Montanari, C.; Gardini, F. Lactic acid bacteria and natural antimicrobials to improve the safety and shelf life of minimally processed sliced apples and lamb's lettuce. Food Microbiol. 2015, 47, 74-84. [CrossRef]

21. Martínez-Hernández, G.B.; Navarro-Rico, J.; Gómez, P.A.; Otón, M.; Artés, F.; Artés-Hernández, F. Combined sustainable sanitising treatments to reduce Escherichia coli and Salmonella Enteritidis growth on fresh-cut kailan-hybrid broccoli. Food Control 2015, 47, 312-317. [CrossRef]

22. Asare, P.T.; Greppi, A.; Stettler, M.; Schwab, C.; Stevens, M.J.A.; Lacroix, C. Decontamination of minimally-processed fresh lettuce using reuterin produced by Lactobacillus reuteri. Front. Microbiol. 2018, 9, 1-12. [CrossRef]

23. Ölmez, H.; Kretzschmar, U. Potential alternative disinfection methods for organic fresh-cut industry for minimizing water consumption and environmental impact. LWT Food Sci. Technol. 2009, 42, 686-693. [CrossRef]

24. Siroli, L.; Patrignani, F.; Serrazanetti, D.I.; Gardini, F.; Lanciotti, R. Innovative strategies based on the use of bio-control agents to improve the safety, shelf life and quality of minimally processed fruits and vegetables. Trends Food Sci. Technol. 2015, 46, 302-310. [CrossRef]

25. Sachadyn-król, M.; Agriopoulou, S. Ozonation as a method of abiotic elicitation improving the health-promoting properties of plant products-A review. Molecules 2020, 25, 2416. [CrossRef]

26. Manolopoulou, E.; Varzakas, T. Minimally processed (fresh-cut) fruits and vegetables. In Handbook of Food Processing: Food Safety, Quality and Manufacturing Processes Contemporary Food Engineering Series; Sun, D.-W., Varzakas, T., Tzia, C., Eds.; CRC Press, Taylor and Francis Group: Boca Raton, FL, USA, 2016; pp. 231-282.

27. Pisoschi, A.M.; Pop, A.; Georgescu, C.; Turcuş, V.; Olah, N.K.; Mathe, E. An overview of natural antimicrobials role in food. Eur. J. Med. Chem. 2018, 143, 922-935. [CrossRef] [PubMed] 
28. Tumbarski, Y.; Nikolova, R.; Petkova, N.; Ivanov, I.; Lante, A. Biopreservation of fresh strawberries by carboxymethyl cellulose edible coatings enriched with a bacteriocin from Bacillus methylotrophicus BM47. Food Technol. Biotechnol. 2019, 57, 230-237. [CrossRef] [PubMed]

29. Leneveu-Jenvrin, C.; Charles, F.; Barba, F.J.; Remize, F. Role of biological control agents and physical treatments in maintaining the quality of fresh and minimally-processed fruit and vegetables. Crit. Rev. Food Sci. Nutr. 2019, 1-19. [CrossRef] [PubMed]

30. Mahajan, B.V.C.; Tandon, R.; Kapoor, S.; Sidhu, M.K. Natural coatings for shelf life enhancement and quality maintenance of fresh fruits and vegetables-A review. J. Postharvest Technol. 2018, 6, 12-26.

31. Yépez, A.; Luz, C.; Meca, G.; Vignolo, G.; Mañes, J.; Aznar, R. Biopreservation potential of lactic acid bacteria from Andean fermented food of vegetal origin. Food Control 2017, 78, 393-400. [CrossRef]

32. Leyva Salas, M.; Mounier, J.; Valence, F.; Coton, M.; Thierry, A.; Coton, E. Antifungal microbial agents for food biopreservation-A review. Microorganisms 2017, 5, 37. [CrossRef]

33. Devi, M.; Jeyanthi Rebecca, L.; Sumathy, S. Bactericidal activity of the lactic acid bacteria Lactobacillus delbreukii. J. Chem. Pharm. Res. 2013, 5, 176-180.

34. Liu, W.; Pang, H.; Zhang, H.; Cai, Y. Biodiversity of lactic acid bacteria. In Lactic Acid Bacteria; Zhang, Y., Cai, Y., Eds.; Springer Science + Business Media: Dordrecht, The Netherlands, 2014.

35. Garcia, C.; Guerin, M.; Souidi, K.; Remize, F. Lactic fermented fruit or vegetable juices: Past, present and future. Beverages 2020, 6, 8. [CrossRef]

36. Kazakos, S.; Mantzourani, I.; Nouska, C.; Alexopoulos, A.; Bezirtzoglou, E.; Bekatorou, A.; Plessas, S.; Varzakas, T. Production of low-alcohol fruit beverages through fermentation of pomegranate and orange juices with kefir grains. Curr. Res. Nutr. Food Sci. 2016, 4, 19-26. [CrossRef]

37. Fessard, A.; Remize, F. Genetic and technological characterization of lactic acid bacteria isolated from tropically grown fruits and vegetables. Int. J. Food Microbiol. 2019, 301, 61-72. [CrossRef]

38. Alvarez-Sieiro, P.; Montalbán-López, M.; Mu, D.; Kuipers, O.P. Bacteriocins of lactic acid bacteria: Extending the family. Appl. Microbiol. Biotechnol. 2016, 100, 2939-2951. [CrossRef] [PubMed]

39. Varzakas, T.; Zakynthinos, G.; Proestos, C.; Radwanska, M. Fermented vegetables. In Minimally Processed and Refrigerated Fruits and Vegetables; Yildiz, F., Wiley, R.C., Eds.; Springer: Boston, MA, USA, 2017; pp. 537-584.

40. Wu, R.; Lu, J. Proteomics of Lactic Acid Bacteria. In Lactic Acid Bacteria; Zhang, Y., Cai, Y., Eds.; Springer Science + Business Media: Dordrecht, The Netherlands, 2014; pp. 249-301.

41. Shoukat, S. Potential anti-carcinogenic effect of probiotic and lactic acid bacteria in detoxification of benzo[a]pyrene: A review. Trends Food Sci. Technol. 2020, 99, 450-459. [CrossRef]

42. Ramos, B.; Miller, F.A.; Brandão, T.R.S.; Teixeira, P.; Silva, C.L.M. Fresh fruits and vegetables-An overview on applied methodologies to improve its quality and safety. Innov. Food Sci. Emerg. Technol. 2013, 20, 1-15. [CrossRef]

43. Ramos, B.; Brandão, T.R.S.; Teixeira, P.; Silva, C.L.M. Biopreservation approaches to reduce Listeria monocytogenes in fresh vegetables. Food Microbiol. 2020, 85, 103282. [CrossRef] [PubMed]

44. Sadiq, F.A.; Yan, B.; Tian, F.; Zhao, J.; Zhang, H.; Chen, W. Lactic acid bacteria as antifungal and anti-mycotoxigenic agents: A comprehensive review. Compr. Rev. Food Sci. Food Saf. 2019, 18, 1403-1436. [CrossRef]

45. Linares-Morales, J.R.; Gutiérrez-Méndez, N.; Rivera-Chavira, B.E.; Pérez-Vega, S.B.; Nevárez-Moorillón, G.V. Biocontrol processes in fruits and fresh produce, the use of lactic acid bacteria as a sustainable option. Front. Sustain. Food Syst. 2018, 2, 50. [CrossRef]

46. Muccilli, S.; Restuccia, C. Bioprotective Role of yeasts. Microorganisms 2015, 3, 588-611. [CrossRef]

47. Sanpa, S.; Sanpa, S.; Suttajit, M. Lactic acid bacteria isolates from Pla-som, their antimicrobial activities and fermentation properties in Pla-som. J. Food Health Bioenviron. Sci. 2019, 12, 36-43.

48. Singh, V.P. Recent approaches in food bio-preservation-A review. Open Vet. J. 2018, 8, 104-111. [CrossRef]

49. Mokoena, M.P. Lactic acid bacteria and their bacteriocins: Classification, biosynthesis and applications against uropathogens: A mini-review. Molecules 2017, 22, 1255. [CrossRef]

50. Khalid, K. An overview of lactic acid bacteria. Int. J. Biosci. 2011, 1, 1-13.

51. Djadouni, F.; Kihal, M. Antimicrobial activity of lactic acid bacteria and the spectrum of their biopeptides against spoiling germs in foods. Braz. Arch. Biol. Technol. 2012, 55, 435-444. [CrossRef] 
52. Zheng, J.; Wittouck, S.; Salvetti, E.; Franz, C.M.A.P.; Harris, H.M.B.; Mattarelli, P.; O’Toole, P.W.; Pot, B.; Vandamme, P.; Walter, J.; et al. A taxonomic note on the genus Lactobacillus: Description of 23 novel genera, emended description of the genus Lactobacillus Beijerinck 1901, and union of Lactobacillaceae and Leuconostocaceae. Int. J. Syst. Evol. Microbiol. 2020, 70, 2782-2858. [CrossRef] [PubMed]

53. Zehra, S.A.; Javed, S.; Nadeem, S.G.; Hakim, S.T. Lactic acid bacteria from fresh fruits and vegetables as biocontrol agent of foodborne bacterial pathogens. RADS J. Biol. Res. Appl. Sci. 2014, 5, 36-45.

54. Bartkiene, E.; Lele, V.; Ruzauskas, M.; Domig, K.J.; Starkute, V.; Zavistanaviciute, P.; Bartkevics, V.; Pugajeva, I.; Klupsaite, D.; Juodeikien, G.; et al. Lactic acid bacteria isolation from spontaneous sourdough and their characterization including antimicrobial and antifungal properties evaluation. Microorganisms 2020, 8, 64 . [CrossRef]

55. Reis, J.A.; Paula, A.T.; Casarotti, S.N.; Penna, A.L.B. Lactic acid bacteria antimicrobial compounds: Characteristics and applications. Food Eng. Rev. 2012, 4, 124-140. [CrossRef]

56. Cálix-Lara, T.F.; Rajendran, M.; Talcott, S.T.; Smith, S.B.; Mille, R.K.; Castillo, A.; Sturino, J.M.; Taylor, T.M. Inhibition of Escherichia coli O157: $\mathrm{H} 7$ and Salmonella enterica on spinach and identification of antimicrobial substances produced by a commercial lactic acid bacteria food safety intervention. Food Microbiol. 2014, 38, 192-200. [CrossRef]

57. Malik, D.K.; Bhatia, D.; Nimbriya, A.; Kumar, S. Lactic acid bacteria and bacteriocin: A Review. J. Pharm. Res. 2012, 5, 2510-2513.

58. Stefanis, C.; Mantzourani, I.; Plessas, S.; Alexopoulos, A.; Galanis, A.; Bezirtzoglou, E.; Kandylis, P.; Varzakas, T. Reviewing classical and molecular techniques regarding profiling of probiotic character of microorganisms. Curr. Res. Nutr. Food Sci. 2016, 4, 27-47. [CrossRef]

59. Dimitrellou, D.; Salamoura, C.; Kontogianni, A.; Katsipi, D.; Kandylis, P.; Zakynthinos, G.; Varzakas, T. Effect of milk type on the microbiological, physicochemical and sensory characteristics of probiotic fermented milk. Microorganisms 2019, 7, 274. [CrossRef]

60. Bron, P.A.; Van Baarlen, P.; Kleerebezem, M. Emerging molecular insights into the interaction between probiotics and the host intestinal mucosa. Nat. Rev. Microbiol. 2012, 10, 66-78. [CrossRef] [PubMed]

61. FAO; WHO. Probiotics in Food: Health and Nutritional Properties and Guidelines for Evaluation; FAO, Food and Nutritional Paper No. 85; FAO: Rome, Italy, 2006; pp. 1-50.

62. Ayala, F.R.; Bauman, C.; Cogliati, S.; Leñini, C.; Bartolini, M.; Grau, R. Microbial flora, probiotics, Bacillus subtilis and the search for a long and healthy human longevity. Microbial. Cell. 2017, 4, 133. [CrossRef] [PubMed]

63. Yang, H.; Sun, Y.; Cai, R.; Chen, Y.; Gu, B. The impact of dietary fiber and probiotics in infectious diseases. Microb. Pathog. 2020, 140, 103931. [CrossRef] [PubMed]

64. Ahlberg, S.H.; Joutsjoki, V.; Korhonen, H.J. Potential of lactic acid bacteria in aflatoxin risk mitigation. Int. J. Food Microbiol. 2015, 207, 87-102. [CrossRef]

65. Agriopoulou, S.; Stamatelopoulou, E.; Varzakas, T. Advances in occurrence, importance, and mycotoxin control strategies: Prevention and detoxification in foods. Foods 2020, 9, 137. [CrossRef] [PubMed]

66. Blagojev, N.; Škrinjar, M.; Vesković-Moračanin, S.; Šošo, V. Control of mould growth and mycotoxin production by lactic acid bacteria metabolites. Rom. Biotechnol. Lett. 2012, 17, 7219-7226.

67. Sathe, S.J.; Nawani, N.N.; Dhakephalkar, P.K.; Kapadnis, B.P. Antifungal lactic acid bacteria with potential to prolong shelf life of fresh vegetables. J. Appl. Microbiol. 2007, 103, 2622-2628. [CrossRef]

68. Machado-Moreira, B.; Richards, K.; Brennan, F.; Abram, F.; Burgess, C.M. Microbial contamination of fresh produce: What, where, and how? Compr. Rev. Food Sci. Food Saf. 2019, 18, 1727-1750. [CrossRef]

69. Lv, X.R.; Ma, H.H.; Lin, Y.; Bai, F.L.; Ge, Y.H.; Zhang, D.F.; Li, J.R. Antifungal activity of Lactobacillus plantarum C10 against Trichothecium roseum and its application in promotion of defense responses in muskmelon (Cucumis melo L.) fruit. J. Food Sci. Technol. 2018, 55, 3703-3711. [CrossRef]

70. Alegre, I.; Abadias, M.; Anguera, M.; Oliveira, M.; Viñas, I. Factors affecting growth of foodborne pathogens on minimally processed apples. Food Microbiol. 2010, 27, 70-76. [CrossRef]

71. Carstens, C.K.; Salazar, J.K.; Darkoh, C. Multistate outbreaks of foodborne illness in the united states associated with fresh produce from 2010 to 2017. Front. Microbiol. 2019, 10, 2667. [CrossRef] [PubMed]

72. CDC (Center for Disease Control and Prevention). Multistate Outbreak of Salmonella Braenderup Infections Associated with Mangoes (Final Update). 2012. Available online: https:/www.cdc.gov/salmonella/ braenderup-08-12/index.html (accessed on 12 May 2020). 
73. CDC (Center for Disease Control and Prevention). Multistate Outbreak of Listeriosis Linked to Commercially Produced, Pre-Packaged Caramel Apples Made from Bidart Bros. Apples (final update). 2015. Available online: https://www.cdc.gov/listeria/outbreaks/caramel-apples-12-14/index.html (accessed on 12 May 2020).

74. Jackson, B.R.; Salter, M.; Tarr, C.; Conrad, A.; Harvey, E.; Steinbock, L.; Saupe, A.; Sorenson, A.; Katz, L.; Stroika, S.; et al. Notes from the field: Listeriosis associated with stone fruit-United States, 2014. Morb. Mortal. Wkly. Rep. 2015, 64, 282-283.

75. Mba-Jonas, A.; Culpepper, W.; Hill, T.; Cantu, V.; Loera, J.; Borders, J.; Saathoff-Huber, L.; Nsubuga, J.; Zambrana, I.; Dalton, S.; et al. A multistate outbreak of human Salmonella Agona infections associated with consumption of fresh, whole papayas imported from Mexico-United States, 2011. Clin. Infect. Dis. 2018, 66, 1756-1761. [CrossRef]

76. Miller, B.D.; Rigdon, C.E.; Robinson, T.J.; Hedberg, C.; Smith, K.E. Use of global trade item numbers in the investigation of a Salmonella newport outbreak associated with blueberries in Minnesota, 2010. J. Food Prot. 2013, 76, 762-769. [CrossRef]

77. CDC (Center for Disease Control and Prevention). Outbreak of Salmonella Infections Linked to Pre-Cut Melons. 2019. Available online: https://www.cdc.gov/salmonella/carrau-04-19/index.html (accessed on 12 May 2020).

78. Olaimat, A.N.; Holley, R.A. Factors influencing the microbial safety of fresh produce: A review. Food Microbiol. 2012, 32, 1-19. [CrossRef] [PubMed]

79. FAO; WHO. Microbiological Hazards in Fresh Fruits and Vegetables; WHO: Geneva, Switzerland, 2008; pp. 1-38.

80. Chlebicz, A.; Śliżewska, K. Campylobacteriosis, salmonellosis, yersiniosis, and listeriosis as zoonotic foodborne diseases: A Review. Int. J. Environ. Res. Public Health. 2018, 15, 863. [CrossRef] [PubMed]

81. Rönnqvist, M.; Välttilä, V.; Ranta, J.; Tuominen, P. Salmonella risk to consumers via pork is related to the Salmonella prevalence in pig feed. Food Microbiol. 2018, 71, 93-97. [CrossRef] [PubMed]

82. Saw, S.H.; Mak, J.L.; Tan, M.H.; Teo, S.T.; Tan, T.Y.; Cheow, M.Y.K.; Ong, C.A.; Chen, S.N.; Yeo, S.K.; Kuan, C.S.; et al. Detection and quantification of Salmonella in fresh vegetables in Perak, Malaysia. Food Res. 2020, 4, 441-448. [CrossRef]

83. Bai, J.; Trinetta, V.; Shi, X.; Noll, L.W.; Magossi, G.; Zheng, W.; Porter, E.P.; Cernicchiaro, N.; Renter, D.G.; Nagaraja, T.G. A multiplex real-time PCR assay, based on inv A and pag C genes, for the detection and quantification of SIalmonella enterica from cattle lymph nodes. J. Microbiol. Methods 2018, 10, 110-116. [CrossRef]

84. Scallan, E.; Hoekstra, R.M.; Angulo, F.J.; Tauxe, R.V.; Widdowson, M.A.; Roy, S.L.; Jones, J.L.; Griffin, P.M. Foodborne illness acquired in the United States-major pathogens. Emerg. Infect. Dis. 2011, 17, 7-15. [CrossRef]

85. Callejón, R.M.; Rodríguez-Naranjo, M.I.; Ubeda, C.; Hornedo-Ortega, R.; Garcia-Parrilla, M.C.; Troncoso, A.M. Reported foodborne outbreaks due to fresh produce in the United States and European Union: Trends and causes. Foodborne Pathog. Dis. 2015, 12, 32-38.

86. Pellegrini, M.; Rossi, C.; Palmieri, S.; Maggio, F.; Chaves-López, C.; Lo Sterzo, C.; Paparella, A.; De Medici, D.; Ricci, A.; Serio, A. Salmonella enterica control in stick carrots through incorporation of coriander seeds essential oil in sustainable washing treatments. Front. Sustain. Food Syst. 2020, 4, 14. [CrossRef]

87. Zhao, X.; Zhao, F.; Wang, J.; Zhong, N. Biofilm formation and control strategies of foodborne pathogens: Food safety perspectives. RSC Adv. 2017, 7, 36670-36683. [CrossRef]

88. EFSA (European Food Safety Authority). The European Union summary report on trends and sources of zoonoses, zoonotic agents and food-borne outbreaks in 2016. EFSA J. 2017, 15, 5077.

89. CDC (Center for Disease Control and Prevention). Outbreak of Salmonella Infections Linked to Cut Fruit. 2020. Available online: https://www.cdc.gov/salmonella/javiana-12-19/index.html (accessed on 12 May 2020).

90. CDC (Center for Disease Control and Prevention). Outbreak of Salmonella Infections Linked to Gavi Brand Whole, Fresh Papayas. 2020. Available online: https://www.cdc.gov/salmonella/uganda-06-19/index.html (accessed on 12 May 2020).

91. CDC (Center for Disease Control and Prevention). Outbreak of Salmonella Poona Infections Linked to Imported Cucumbers (Final Update). 2016. Available online: https://www.cdc.gov/salmonella/poona-09-15/ index.html (accessed on 12 May 2020). 
92. CDC (Center for Disease Control and Prevention). Outbreak of Listeria Infections Linked to Enoki Mushrooms. 2020. Available online: https:/www.cdc.gov/listeria/outbreaks/enoki-mushrooms-03-20/index. html (accessed on 12 May 2020).

93. CDC (Center for Disease Control and Prevention). Outbreak of Listeriosis Linked to Whole Cantaloupes from Jensen Farms, Colorando (Final Update). 2012. Available online: https:/www.cdc.gov/listeria/outbreaks/ cantaloupes-jensen-farms/index.html (accessed on 12 May 2020).

94. CDC (Center for Disease Control and Prevention). Outbreak of E. coli Linked to Romaine Lettuce. 2020. Available online: https://www.cdc.gov/ecoli/2019/o157h7-11-19/index.html (accessed on 12 May 2020).

95. CDC (Center for Disease Control and Prevention). Multistate Outbreak of E. coli O 157:H7 Infections Linked to Romaine Lettuce (Final Update). 2018. Available online: https:/www.cdc.gov/ecoli/2018/o157h7-04-18/ index.html (accessed on 12 May 2020).

96. CDC (Center for Disease Control and Prevention). Multistate Outbreak of Shiga Toxin-Producing Escherichia coli O 157:H7 Infections Linked to Leafy Greens (Final Update). 2018. Available online: https://www.cdc. gov/ecoli/2017/o157h7-12-17/index.html (accessed on 12 May 2020).

97. Dubreuil, J.D. Fruit extracts to control pathogenic Escherichia coli: A sweet solution. Heliyon 2020, 6, e03410. [CrossRef]

98. Luna-Guevara, J.J.; Arenas-Hernandez, M.M.P.; Martínez De La Peña, C.; Silva, J.L.; Luna-Guevara, M.L. The role of pathogenic E. coli in fresh vegetables: Behavior, contamination factors, and preventive measures. Int. J. Microbiol. 2019, 2019, 2894328. [CrossRef]

99. Soon, J.M.; Seamanc, P.; Baines, R.N. Escherichia coli O104:H4 outbreak from sprouted seeds. Int. J. Hyg. Environ. Health 2013, 216, 346-354. [CrossRef]

100. Zhu, Q.; Gooneratne, R.; Hussain, M. Listeria monocytogenes in fresh produce: Outbreaks, prevalence and contamination levels. Foods 2017, 6, 21. [CrossRef]

101. Lokerse, R.F.A.; Maslowska-Corker, K.A.; van de Wardt, L.C.; Wijtzes, T. Growth capacity of Listeria monocytogenes in ingredients of ready-to-eat salads. Food Control 2016, 60, 338-345. [CrossRef]

102. Truchado, P.; Elsser-Gravesen, A.; Gil, M.I.; Allende, A. Post-process treatments are effective strategies to reduce Listeria monocytogenes on the surface of leafy greens: A pilot study. Int. J. Food Microbiol. 2020, 313, 108390. [CrossRef]

103. EFSA (European Food Safety Authority). The European Union one health 2018 zoonoses report, European Food Safety Authority and European Centre for Disease Prevention and Control (EFSA and ECDC). EFSA J. 2019, 17, 5926.

104. Cherukuri, P.J.; Narayanan, R.; Akkina, R.C. Production and preliminary characterization of bacteriocin from Enterococcus Faecium against Listeria Monocytogenes. Asian J. Microbiol. Biotechnol. Environ. Sci. 2019, 21, 1033-1040.

105. Ukuku, D.O.; Niemira, B.A.; Ukanalis, J. Nisin-based antimircobial combination with cold plasma treatment inactivate Listeria monocytogenes on Granny Smith apples. LWT 2019, 104, 120-127. [CrossRef]

106. Oliveira, M.; Abadias, M.; Colás-Medà, P.; Usall, J.; Viñas, I. Biopreservative methods to control the growth of foodborne pathogens on fresh-cut lettuce. Int. J. Food Microbiol. 2015, 214, 4-11. [CrossRef] [PubMed]

107. Yildiz, H.; Karatas, N. Microbial exopolysaccharides: Resources and bioactive properties. Process Biochem. 2018, 72, 41-46. [CrossRef]

108. Oliveira, M.; Abadias, M.; Usall, J.; Torres, R.; Teixidó, N.; Viñas, I. Application of modified atmosphere packaging as a safety approach to fresh-cut fruits and vegetables-A review. Trends Food Sci. Technol. 2015, 46, 13-26. [CrossRef]

109. Dong, Q.; Zhang, W.; Guo, L.; Niu, H.; Liu, Q.; Wang, X. Influence of Lactobacillus plantarum individually and in combination with low $\mathrm{O}_{2}$-MAP on the pathogenic potential of Listeria monocytogenes in cabbage. Food Control 2020, 107, 106765. [CrossRef]

110. Vescovo, M.; Torriani, S.; Orsi, C.; Macchiarolo, F.; Scolari, G. Application of antimicrobial-producing lactic acid bacteria to control pathogens in ready-to-use vegetables. J. Appl. Microbiol. 1996, 81, 113-119. [CrossRef]

111. Torriani, S.; Orsi, C.; Vescovo, M. Potential of Lactobacillus casei, culture permeate, and lactic acid to control microorganisms in ready-to-use vegetables. J. Food Prot. 1997, 60, 1564-1567. [CrossRef]

112. Li, J.; Bai, J.; Li, S.; Zue, Z.; Yi, Y.; Wang, H.; Lamikanra, O. Effect of lactic acid bacteria on the postharvest properties of fresh lotus root. Postharvest Biol. Technol. 2020, 160, 110983. [CrossRef] 
113. Alegre, I.; Viñas, I.; Usall, J.; Anguera, M.; Altisent, R.; Abadias, M. Antagonistic effect of Pseudomonas graminis CPA-7 against foodborne pathogens in fresh-cut apples under simulated commercial conditions. Food Microbiol. 2013, 33, 139-148. [CrossRef] [PubMed]

114. Abadias, M.; Altisent, R.; Usall, J.; Torres, R.; Oliveira, M.; Viñas, I. Biopreservation of fresh-cut melon using the strain Pseudomonas graminis CPA-7. Postharvest Biol. Technol. 2014, 96, 69-77. [CrossRef]

115. Iglesias, M.B.; Echeverría, G.; Viñas, I.; López, M.L.; Abadias, M. Biopreservation of fresh-cut pear using Lactobacillus rhamnosus GG and effect on quality and volatile compounds. LWT Food Sci. Technol. 2018, 87, 581-588. [CrossRef]

116. Fang, X.; Duan, Q.; Wang, Z.; Li, F.; Du, J.; Ke, W.; Liu, D.; Ross, C.B.; Xusheng, G.; Ying, Z. Products of Lactobacillus delbrueckii subsp. bulgaricus strain F17 and Leuconostoc lactis strain H52 are biopreservatives for improving postharvest quality of 'Red Globe' grapes. Microorganisms 2020, 8, 656.

117. Yi, L.; Qi, T.; Ma, J.; Zeng, K. Genome and metabolites analysis reveal insights into control of foodborne pathogens in fresh-cut fruits by Lactobacillus pentosus MS031 isolated from Chinese sichuan paocai. Postharvest Biol. Technol. 2020, 164, 111150. [CrossRef]

118. Russo, P.; Peña, N.; de Chiara, M.L.V.; Amodio, M.L.; Colelli, G.; Spano, G. Probiotic lactic acid bacteria for the production of multifunctional fresh-cut cantaloupe. Food Res. Int. 2015, 77, 762-772. [CrossRef]

119. Martínez-Castellanos, G.; Pelayo-Zaldívar, C.; Pérez-Flores, L.J.; López-Luna, A.; Gimeno, M.; Bárzana, E.; Shirai, K. Postharvest litchi (Litchi chinensis Sonn.) quality preservation by Lactobacillus plantarum. Postharvest Biol. Technol. 2011, 59, 172-178. [CrossRef]

120. Parada, J.L.; Caron, C.R.; Medeiros, A.B.P.; Soccol, C.R. Bacteriocins from lactic acid bacteria: Purification, properties and use as biopreservatives. Braz. Arch. Biol. Technol. 2007, 50, 521-542. [CrossRef]

121. Zacharof, M.P.; Lovitt, R.W. Bacteriocins produced by lactic acid bacteria: A review article. APCBEE Procedia 2012, 2, 50-56. [CrossRef]

122. George, F.; Daniel, C.; Thomas, M.; Singer, E.; Guilbaud, A.; Tessier, F.J.; Revol-Junelles, A.M.; Borges, F.; Foligné, B. Occurrence and dynamism of lactic acid bacteria in distinct ecological niches: A multifaceted functional health perspective. Front. Microbiol. 2018, 9, 2899. [CrossRef]

123. Mani-lópez, E.; Palou, E.; López-malo, A. Biopreservatives as agents to prevent food spoilage. In Microbial Contamination and Food Degradation; Elsevier: Amsterdam, The Netherlands, 2018; pp. 235-270.

124. Juturu, V.; Wu, J.C. Microbial production of bacteriocins: Latest research development and applications. Biotechnol. Adv. 2018, 36, 2187-2200. [CrossRef] [PubMed]

125. Sharma, V.; Ranveer, R.C.; Jain, N.; Aseri, G.K. Bacteriocins: Production, different strategies of purification and applications. Int. J. Res. Pharm. Sci. 2019, 10, 1808-1817.

126. O'Connor, P.M.; Ross, R.P.; Hill, C.; Cotter, P.D. Antimicrobial antagonists against food pathogens: A bacteriocin perspective. Curr. Opin. Food Sci. 2015, 2, 51-57. [CrossRef]

127. Snyder, A.B.; Worobo, R.W. Chemical and genetic characterization of bacteriocins: Antimicrobial peptides for food safety. J. Sci. Food Agric. 2014, 94, 28-44. [CrossRef] [PubMed]

128. Tumbarski, Y.; Lante, A.; Krastanov, A. Immobilization of bacteriocins from lactic acid bacteria and possibilities for application in food biopreservation. Open Biotechnol. J. 2018, 12, 25-32. [CrossRef]

129. Barbosa, A.A.T.; Silva de Araújo, H.G.; Matos, P.N.; Carnelossi, M.A.G.; Almeida de Castro, A. Effects of nisin-incorporated films on the microbiological and physicochemical quality of minimally processed mangoes. Int. J. Food Microbiol. 2013, 164, 135-140. [CrossRef]

130. De Carvalho, A.A.T.; Mantovani, H.C.; Vanetti, M.C.D. Bactericidal effect of bovicin HC5 and nisin against Clostridium tyrobutyricum isolated from spoiled mango pulp. Lett. Appl. Microbiol. 2007, 45, 68-74. [CrossRef]

131. Gálvez, A.; Abriouel, H.; López, R.L.; Omar, N.B. Bacteriocin-based strategies for food Biopreservation. Int. J. Food Microbiol. 2007, 120, 51-70. [CrossRef]

132. Barbosa, A.A.; Mantovani, H.C.; Jain, S. Bacteriocins from lactic acid bacteria and their potential in the preservation of fruit products. Crit Rev. Biotechnol. 2017, 37, 852-864. [CrossRef]

133. Miao, J.; Zhou, J.; Liu, G.; Chen, F.; Chen, Y.; Gao, X.; Dixon, W.; Song, M.; Xiao, H.; Cao, Y. Membrane disruption and DNA binding of Staphylococcus aureus cell induced by a novel antimicrobial peptide produced by Lactobacillus paracasei subsp. tolerans FX-6. Food Control 2016, 59, 609-613. [CrossRef]

134. Field, D.; Ross, R.P.; Hill, C. Developing bacteriocins of lactic acid bacteria into next generation biopreservatives. Curr. Opin. Food Sci. 2018, 20, 1-6. [CrossRef] 
135. Abee, T.; Krockel, L.; Hill, C. Bacteriocins: Modes of action and potentials in food preservation and control of food poisoning. Int. J. Food Microbiol. 1995, 28, 169-185. [CrossRef]

136. Quinto, E.J.; Caro, I.; Villalobos-Delgado, L.H.; Mateo, J.; De-Mateo-silleras, B.; Redondo-Del-río, M.P. Food safety through natural antimicrobials. Antibiotics 2019, 8, 208. [CrossRef] [PubMed]

137. Radaic, A.; de Jesus, M.B.; Kapila, Y.L. Bacterial anti-microbial peptides and nano-sized drug delivery systems: The state of the art toward improved bacteriocins. J. Control. Release 2020, 321, 100-118. [CrossRef] [PubMed]

138. Castro-Rosas, J.; Ferreira-Grosso, C.R.; Gómez-Aldapa, C.A.; Rangel-Vargas, E.; Rodríguez-Marín, M.L.; Guzmán-Ortiz, F.A.; Falfan-Corte, R.N. Recent advances in microencapsulation of natural sources of antimicrobial compounds used in food-A review. Food Res. Int. 2017, 102, 575-587. [CrossRef]

139. Carocho, M.; Morales, P.; Ferreira, I.C.F.R. Natural food additives: Quo vadis? Trends Food Sci. Technol. 2015, 45, 284-295. [CrossRef]

140. Klaenhammer, T.R. Genetics of bacteriocins produced by lactic acid bacteria. FEMS Microbiol. Rev. 1993, 12, 39-85. [CrossRef]

141. Ahmad, V.; Khan, M.S.; Jamal, Q.M.S.; Alzohairy, M.A.; Al Karaawi, M.A.; Siddiqui, M.U. Antimicrobial potential of bacteriocins: In therapy, agriculture and food preservation. Int. J. Antimicrob. Agents 2017, 49, 1-11. [CrossRef]

142. Bahrami, A.; Delshadi, R.; Assadpour, E.; Jafari, S.M.; Williams, L. Antimicrobial-loaded nanocarriers for food packaging applications. Adv. Colloid Interface Sci. 2020, 278, 102140. [CrossRef]

143. Orji, J.O.; Amaobi, C.B.; Moses, I.B.; Uzoh, C.V.; Emioye, A.A. Antagonistic effect and bacteriocinogenic activity of Lactic Acid Bacteria isolated from Sorghum bicolor-Based 'ogi' on food borne bacterial pathogens from cabbage. Afr. J. Clin. Exper. Microbiol. 2020, 21, 45-52. [CrossRef]

144. Settanni, L.; Corsetti, A. Application of bacteriocins in vegetable food biopreservation. Int. J. Food Microbiol. 2008, 121, 123-138. [CrossRef] [PubMed]

145. Dhundale, V.; Hemke, V.; Desai, D.; Dhundale, P. Evaluation and exploration of lactic acid bacteria for preservation and extending the shelf life of fruit. Int. J. Fruit Sci. 2018, 18, 355-368. [CrossRef]

146. McManamon, O.; Kaupper, T.; Scollard, J.; Schmalenberger, A. Nisin application delays growth of Listeria monocytogenes on fresh-cut iceberg lettuce in modified atmosphere packaging, while the bacterial community structure changes within one week of storage. Postharvest Biol. Technol. 2019, 147, 185-195. [CrossRef]

147. Skariyachan, S.; Govindarajan, S. Biopreservation potential of antimicrobial protein producing Pediococcus spp. towards selected food samples in comparison with chemical preservatives. Int. J. Food Microbiol. 2019, 291, 189-196. [CrossRef] [PubMed]

148. Ajingi, Y.S.; Ruengvisesh, S.; Khunrae, P.; Rattanarojpong, T.; Jongruja, N. The combined effect of formic acid and Nisin on potato spoilage. Biocatal. Agric. Biotechnol. 2020, 24, 101523. [CrossRef]

149. Issouffou, C.; Suwansri, S.; Salaipeth, L.; Domig, K.J.; Hwanhlem, N. Synergistic effect of essential oils and enterocin KT2W2G on the growth of spoilage microorganisms isolated from spoiled banana peel. Food Control 2018, 89, 260-269. [CrossRef]

150. Ukuku, D.O.; Bari, M.L.; Kawamoto, S.; Isshiki, K. Use of hydrogen peroxide in combination with nisin, sodium lactate and citric acid for reducing transfer of bacterial pathogens from whole melon surfaces to fresh-cut pieces. Int. J. Food Microbiol. 2005, 104, 225-233. [CrossRef]

151. Molinos, A.C.; Abriouel, H.; Omar, N.B.; Lucas, R.; Valdivia, E.; Gálvez, A. Inactivation of Listeria monocytogenes in raw fruits by enterocin AS-48. J. Food Prot. 2008, 71, 2460-2467. [CrossRef]

152. Allende, A.; Martínez, B.; Selma, V.; Gil, M.I.; Suárez, J.E.; Rodríguez, A. Growth and bacteriocin production by lactic acid bacteria in vegetable broth and their effectiveness at reducing Listeria monocytogenes in vitro and in fresh-cut lettuce. Food Microbiol. 2007, 24, 759-766. [CrossRef]

153. European Parliament; The Concil of the European Union. Regulation (EC) No 1333/2008 of the European Parliament ans of the Council of 16 December 2998 on food additives. Off. J. Eur. Union 2008, L354, 16-33.

154. Balciunas, E.M.; Martinez, F.A.; Todorov, S.D.; de Melo Franco, B.D.; Converti, A.; de Souza Oliveira, R.P. Novel biotechnological applications of bacteriocins: A review. Food Control 2013, 32, 134-142. [CrossRef]

155. CFR. Direct Food Substances Affirmed as Generally Recognized as Safe. United States Code of Federal Regulations (Title 21 Foods and Drugs. Part 184). 2019. Available online: https://www.accessdata.fda.gov/ scripts/cdrh/cfdocs/cfcfr/CFRSearch.cfm? (accessed on 19 May 2020). 
156. Zhou, H.; Fang, J.; Tian, Y.; Lu, X.Y. Mechanisms of nisin resistance in Gram-positive bacteria. Ann. Microbiol. 2014, 64, 413-420. [CrossRef]

157. Mathur, H.; Field, D.; Rea, M.C.; Cotter, P.D.; Hill, C.; Ross, R.P. Bacteriocin-antimicrobial synergy: A medical and food perspective. Front. Microbiol. 2017, 8, 1205. [CrossRef] [PubMed]

158. Rajendran, K.; Nagappan, R.; Ramamurthy, K. A study on the bactericidal effect of nisin purified from Lactococcus lactis. Ethiop. J. Biol. Sci. 2011, 10, 95-102.

159. Gardini, F.; Siroli, L.; Patrignani, F.; Salvetti, E.; Torriani, S.; Lanciotti, R. Use of a nisin-producing Lactococcus lactis strain, combined with thyme essential oil, to improve the safety and shelf life of minimally processed lamb's lettuce. In Proceedings of the 11th International Symposium on Lactic Acid Bacteria, Egmond aan Zee, The Netherlands, 31 August-4 September 2014.

160. Porto, M.C.W.; Kuniyoshi, T.M.; Azevedo, P.O.S.; Vitolo, M.; Oliveira, R.P.S. Pediococcus spp.: An important genus of lactic acid bacteria and pediocin producers. Biotechnol. Adv. 2017, 35, 361-374. [CrossRef]

161. Engelhardt, T.; Albano, H.; Kiskó, G.; Mohácsi-Farkas, C.; Teixeira, P. Antilisterial activity of bacteriocinogenic Pediococcus acidilactici HA6111-2 and Lactobacillus plantarum ESB 202 grown under $\mathrm{pH}$ and osmotic stress conditions. Food Microbiol. 2015, 48, 109-115. [CrossRef]

162. Sun, L.; Song, H.; Zheng, W. Improvement of antimicrobial activity of pediocin PA-1 by site-directed mutagenesis in C-terminal domain. Protein Pept. Lett. 2015, 22, 1007-1012. [CrossRef]

163. Espitia, P.J.P.; Soares, N.F.F.; Teófilo, R.F.; Coimbra, J.S.R.; Vitor, D.M.; Batista, R.A.; Ferreira, S.O.; Andrade, N.J.; Medeiros, E.A.A. Physical-mechanical and antimicrobial properties of nanocomposite films with pediocin and ZnO nanoparticles. Carbohydr. Polym. 2013, 94, 199-208. [CrossRef]

164. Rojas-Graü, M.A.; Soliva-Fortuny, R.; Martín-Belloso, O. Edible coatings to incorporate active ingredients to fresh-cut fruits: A review. Trends Food Sci. Technol. 2009, 20, 438-447. [CrossRef]

165. Guimarães, A.; Abrunhosa, L.; Pastrana, L.M.; Cerqueira, M.A. Edible films and coatings as carriers of living microorganisms: A new strategy towards biopreservation and healthier foods. Compr. Rev. Food Sci. Food Saf. 2018, 17, 594-614. [CrossRef]

166. Vieira, A.I.; Guerreiro, A.; Antunes, M.D.; Miguel, M.G.; Faleiro, M. Edible coatings enriched with essential oils on apples impair the survival of bacterial pathogens through a simulated gastrointestinal system. Foods 2019, 8, 57. [CrossRef]

167. Pop, O.L.; Pop, C.R.; Dufrechou, M.; Vodnar, D.C.; Socaci, S.A.; Dulf, F.V.; Minervini, F.; Suharosch, R. Edible films and coatings functionalization by probiotic incorporation: A review. Polymers 2020, 12, 12. [CrossRef] [PubMed]

168. Guo, M.; Jin, T.Z.; Gurtler, J.B.; Fan, X.; Yadav, M.P. Inactivation of Escherichia coli O157:H7 and Salmonella and native microbiota on fresh strawberries by antimicrobial washing and coating. J. Food Prot. 2018, 81, 1227-1235. [CrossRef]

169. Tapia, M.S.; Rojas-Graü, M.A.; Rodríguez, F.J.; Ramírez, J.; Carmona, A.; Martin-Belloso, O. Alginate-and gellan-based edible films for probiotic coatings on fresh-cut fruits. J. Food Sci. 2007, 72, 190-196. [CrossRef] [PubMed]

170. Tenea, G.N.; Olmedo, D.; Ortega, C. Peptide-based formulation from lactic acid bacteria impairs the pathogen growth in Ananas Comosus (Pineapple). Coatings 2020, 10, 457. [CrossRef]

171. Tenea, G.N.; Pozo, T.D. Antimicrobial peptides from Lactobacillus plantarum UTNGt2 prevent harmful bacteria growth on fresh tomatoes. J. Microbiol. Biotechnol. 2019, 29, 1553-1560. [CrossRef]

172. Khodaei, D.; Hamidi-Esfahani, Z. Influence of bioactive edible coatings loaded with Lactobacillus plantarum on physicochemical properties of fresh strawberries. Postharvest Biol. Technol. 2019, 156, 110944. [CrossRef]

173. Bambace, M.F.; Alvarez, M.V.; del Rosario Moreira, M. Novel functional blueberries: Fructo-oligosaccharides and probiotic lactobacilli incorporated into alginate edible coatings. Food Res. Int. 2019, 122, 653-660. [CrossRef]

174. Narsaiah, K.; Wilson, R.A.; Gokul, K.; Mandge, H.M.; Jha, S.N.; Bhadwal, S.; Anurag, R.K.; Malik, R.K.; Vij, S. Effect of bacteriocin-incorporated alginate coating on shelf life of minimally processed papaya (Carica papaya L.). Postharvest Biol. Technol. 2015, 100, 212-218. [CrossRef]

(C) 2020 by the authors. Licensee MDPI, Basel, Switzerland. This article is an open access article distributed under the terms and conditions of the Creative Commons Attribution (CC BY) license (http://creativecommons.org/licenses/by/4.0/). 